\title{
A survey of the Alopecosa cursor species group (Aranei: Lycosidae) from Asia
}

\section{Обзор группы видов Alopecosa cursor (Aranei: Lycosidae) из Азии}

\author{
Yu.M. Marusilk, ${ }^{1,2,3}$, A.A. Nadolny ${ }^{4}$, S. Koponen ${ }^{3}$ \\ Ю.М. Марусик ${ }^{1,2,3}$, А.А. Надольный ${ }^{4}$, С. Копонен ${ }^{3}$
}

\author{
${ }^{1}$ Institute for Biological Problems of the North RAS, Portovaya Str. 18, Magadan 685000, Russia. \\ ${ }^{1}$ Институт биологических проблем Севера ДВО РАН, ул. Портовая 18, Магадан 685000 Россия. \\ ${ }^{2}$ Department of Zoology \& Entomology, University of the Free State, Bloemfontein 9300, South Africa. \\ ${ }^{3}$ Zoological Museum, Biodiversity Unit, FI-20014 University of Turku, Finland. E-mail: yurmar@mail.ru, sepkopo@utu.fi \\ ${ }^{4}$ Institute of Marine Biological Research of Russian Academy of Sciences, Nakhimov Avenue 2, Sevastopol 299011 Crimea. E-mail: \\ nadolnyanton@mail.ru
}

KEY WORDS: Araneae, Lycosinae, Pardosa, Xinjiang, Central Asia, Caucasus, Crimea, sibling species.

КЛЮЧЕВЫЕ СЛОВА: Araneae, Lycosinae, Pardosa, Синьцзян, Центральная Азия, Кавказ, Крым, видыдвойники.

ABSTRACT. Species belonging to the Alopecosa cursor group from Central Asia have been surveyed. Four species are recognized: A. cursor (Hahn, 1831) $\left(O^{\top}+\right.$, Iberian Peninsula to Northern Xinjiang and Altai), A. cursorioides Charitonov, 1969 ( $0^{7}$, Uzbekistan, Turkmenistan and possibly NE Iran), A. passibilis (O. Pickard-Cambridge, 1885) ( $\sigma^{\top}$, SW Xinjiang), and A. pentheri (Nosek, 1905) ( $\sigma^{7}+$, Italy to Azerbaijan). Alopecosa cursorioides stat.n. was originally described as a subspecies of A. cursor. A new combination, Alopecosa passibilis comb.n., is suggested for the species originally described in Lycosa and currently considered in Pardosa. A. cursor and A. pentheri occur sympatrically in the Crimea and Caucasus. Faunistic records of these species are often mixed up due to indistinguishable females. Detailed information of distribution, habitat preferences, and phenology of A. cursor and $A$. pentheri in the Crimea are provided.

How to cite this article: Marusik Yu.M., Nadolny A.A., Koponen S. 2018. A survey of the Alopecosa cursor species group (Aranei: Lycosidae) from Asia // Arthropoda Selecta. Vol.27. No.4. P.348-362. doi: 10.15298/arthsel. 27.4.12

РЕЗЮМЕ. Исследованы четыре вида группы Alopecosa cursor из Центральной Азии: A. cursor (Hahn, 1831) ( ${ }^{7}$ - , от Пиренейского полуострова до северного Синьцзяна и Алтая), A. cursorioides Charitonov, 1969 ( $\bigcirc^{\top}$, Узбекистан, Туркменистан и возможно северо-восточный Иран), A. passibilis (O. Pickard-Cambridge, 1885) ( $\sigma^{7}$, юго-западный Синьцзян) и A. pentheri (Nosek, 1905) ( $\bigcirc^{\top}$, от Италии до Азербайджана). Вид Alopecosa cursorioides stat.n. изначально был описан как подвид A. cursor. Предложена новая комбинация, Alopecosa passibilis comb.n., для вида, который был описан в составе рода Lycosa и до сих пор находившийся в составе рода Pardosa. Выяснено, что в Крыму и на Кавказе A. cursor и A. pentheri обитают симпатрично. Самки этих видов морфологически неразличимы и поэтому фаунистические указания $A$. cursor и $A$. pentheri часто перепутаны. Приводятся данные о распространении, биотопической приуроченности и фенологии A. cursor и A. pentheri в Крыму.

\section{Introduction}

Alopecosa Simon, 1885 is one of the most species rich genera in the family Lycosidae with 161 named and currently valid species [WSC, 2018]. Most species are known from the Holarctic, and 16 species, most likely misplaced, are known from Australia, South East Asia, Africa, and South America. So far, only West Palaearctic Alopecosa have been split into species groups. Lugetti \& Tongiorgi [1969] recognized five species groups: fabrilis, pulverulenta, cursor, sulzeri, and striatipes. While studying types of Lycosidae described by O. Pickard-Cambridge [1885] based on the material collected during the Second Yarkand Mission in the Himalaya and Tibet, we recognized one species, A. passibilis (O. Pickard-Cambridge, 1885), resembling A. cursor (Hahn, 1831). Comparison of A. passibilis with other members of this group occurring in southeast Europe and Asia, A. cursor, A. pentheri (Nosek, 1905), and A. cursor cursorioides Charitonov, 1969, reveals that all can be considered separate species. All are very similar to each other; one of them, $A$. passibilis, was never illustrated and is currently considered in Pardosa [WSC, 2018]; A. cursor cursorioides Charitonov, 1969 is known only from the original description and only very schematic drawings. Therefore, we present a survey of the A. cursor group from Asia. 


\section{Material and Methods}

Specimens were photographed at the Zoological Museum, University of Turku, Finland with a Canon EOS 7D camera attached to an Olympus SZX16 stereomicroscope and a SEM JEOL JSM-5200 scanning microscope.

Digital images were montaged using CombineZP and Helicon focus 3.10 image stacking software. Epigynes were cleared in a $\mathrm{KOH} /$ water solution until soft tissues were dissolved. Photographs were taken in dishes with paraffin on the bottom holding the specimens in place. All measurements are given in millimeters. Lengths of leg segments were measured on the dorsal side. Measurements for leg segments are given as follows: total (femur, patella, tibia, metatarsus, tarsus). Leg measurements are given in text and as tables in Appendix 1, just to make comparison easier. Tables in the Appendix are marked with suffix "a".

Abbreviations in the text: a - apical, d - dorsal, $\mathrm{Fe}$ - femur, Mt - metatarsus, $\mathrm{p}$ - prolateral, $\mathrm{Pa}$ patella, $\mathrm{r}$ - retrolateral, Ta - tarsus, Ti - tibia, $\mathrm{v}-$ ventral. The collectors' names are abbreviated as follows: A.N. - A.A. Nadolny; M.K. - M.M. Kovblyuk.

The material is housed in the Zoological Museum of the Moscow State University, Russia (ZMMU), the Zoological Museum of the University of Turku, Finland (ZMUT), the National Arachnological Collection, Department of Zoology, V.I. Vernadsky Taurida National University, Simferopol, Crimea (TNU), the Oxford University Museum of Natural History, England (OUMNH), and Institute of Systematics and Ecology of Animals, Novosibirsk, Russia (ISEA).

\section{Taxonomy}

Lycosidae Sundevall, 1833

Alopecosa Simon, 1885

Type species: Araneus fabrilis Clerck, 1757.

\section{Alopecosa cursor group}

COMPOSITION AND HISTORY. Lugetti \& Tongiorgi [1969] subdivided Alopecosa species occurring in Europe into five species groups: fabrilis, pulverulenta, cursor, sulzeri, and striatipes. Six species and subspecies have been assigned to the cursor group: A. cursor cursor, A. cursor pentheri, A. insignis (Nosek, 1905), A. etrusca Lugetti et
Tongiorgi, 1969, A. simoni (Thorell, 1872), and A. osellai Lugetti et Tongiorgi, 1969. Currently, A. pentheri is considered a separate species [Thaler et al., 2000; WSC, 2018], and Alopecosa insignis has been synonymized with A. pentheri [Thaler et al., 2000: 1073]. One subspecies belonging to the cursor group, A. cursor cursorioides Charitonov, 1969 , was not considered in the revision by Lugetti \& Tongiorgi [1969] because it had not been described from Europe, but from Uzbekistan, and was published simultaneously with Lugetti \& Tongiorgi [1969]. Thus, currently, six species and subspecies are assigned to the cursor group: $A$. cursor cursor, A. c. cursorioides, A. etrusca, A. pentheri, A. simoni, and A. osellai.

The morphology of the male palp and epigyne indicate that two species, A. simoni and A. osellai, are misplaced in the group. These species have 2 pairs of receptacles instead of one, and the tegular apophysis does not have 2 distinct outgrowths [Lugetti, Tongiorgi, 1969: figs. 17b-f, 18b-f].

This study reveals that the subspecies A. cursor cursorioides should be considered a separate species, A. cursorioides. In addition, it was found that species described as Lycosa passibilis O. Pickard-Cambridge, 1885 and now placed in Pardosa actually belongs to the cursor group. Thus, we consider this group to contain five species: A. cursor, A. cursorioides, A. etrusca, A. passibilis, and A. pentheri. Although A. etrusca has been reported from Asia, specifically Azerbaijan and Turkey, it apparently does not occur in Asia and is not considered here. Records from both countries are doubtful and most likely refer to A. cursor or A. pentheri.

DIAGNOSIS. Males of the A. cursor group can be distinguished from other Alopecosa species groups by having a prominent outgrowth of the tegular apophysis (lacking or small in other groups), lacking a synembolus (known in all other groups), and a simple, unmodified embolus (some species groups have an embolus with accompanying membrane - e.g. A. pulverulenta group, or the tip of the embolus is harpoon-like - e.g. A. striatipes group).

Females of the A. cursor group can be recognized by the large pentagonal septum with a very short stalk $(E s)$, the septum covering the entire fovea, each receptacle with several (5-10) wart-like outgrowths $(W r)$ covered with glands, and an endogyne lacking accessoriy receptacles. Other species groups have either 2 pairs of receptacles (each with $<5$ wart-like glands), the septum is not pentagonal, or the stalk of the septum is long.

DESCRIPTION. Body length in males 5.8-6.7 and females 6.1-9.4. Carapace and abdominal pattern in all species almost the same - grey, brown, or dark-brown with a dorsal pattern (Fig. 1: A, D, F). Carapace with light median, dark lateral (reaching second row of eyes), and light narrow marginal stripes. Abdomen with dark lanceolate cardiac mark and 4 light brown triangular spots. The pattern in males and females is rather similar, although the abdominal pattern in males can be less distinct. Leg spination is the same for all species in the cursor group, and females have fewer spines than males (Tables 1-2).

Table 1. Leg spination in males of the A. cursor group.

Таблица 1. Вооружение ног самцов пауков группы A. cursor.

\begin{tabular}{|l|l|l|l|l|}
\hline & \multicolumn{1}{|c|}{ Femur } & Patella & \multicolumn{1}{c|}{ Tibia } & \multicolumn{1}{c|}{ Metatarsus } \\
\hline I & d1-1-1, p1, r1-1 & - & p1-1, r1-1, v2-2-2a & p1-1-1a, r1-1a, v2-2-3a \\
\hline II & d1-1-1, p1, r1-1-1 & p1, r1 & p1-1, r1-1, v2-2-2a & p1-1-1a, r1-1a, v2-2-3a \\
\hline III & d1-1-1, p1-1, r1-1-1 & p1, r1 & d1-1, p1-1, r1-1, v2-2-2a & p1-1-1a, r1-1-1a, v2-2-3a \\
\hline IV & d1-1-1, p1-1, r1 & p1, r1 & d1-1, p1-1, r1-1, v2-2-2a & p1-1-1a, r1-1-1a, v2-2-3a \\
\hline
\end{tabular}


Table 2. Leg spination in females of the A. cursor group.

Таблица 2. Вооружение ног самок пауков группы A. cursor.

\begin{tabular}{|l|l|l|l|l|}
\hline & \multicolumn{1}{|c|}{ Femur } & Patella & \multicolumn{1}{c|}{ Tibia } & \multicolumn{1}{c|}{ Metatarsus } \\
\hline I & d1-1-1, p1 & - & p1-1, v2-2-2a & p1-1, v2-2-2a \\
\hline II & d1-1-1, p1-1, r1-1-1 & - & p1-1, v2-2-2a & p1-1, v2-2-2a \\
\hline III & d1-1-1, p1-1, r1-1-1 & p1, r1 & d1-1, p1-1, r1-1, v2-2-2a & p1-1-1a, r1-1-1a, v2-2-3a \\
\hline IV & d1-1-1, p1-1, r1 & p1, r1 & d1-1, p1-1, r1-1, v2-2-2a & p1-1-1a, r1-1-1a, v2-2-3a \\
\hline
\end{tabular}

Male palp. Cymbium as in other species groups, with a relatively long and tapering tip, lacking claws. Bulb 1.231.3 times longer than wide. Subtegulum located medially, not prolaterally as in most other groups; tegulum with distinct prolateral tip $(T t)$, which can be hidden by embolus ventrally; tegular apophysis square-shaped, extending retroanteriorly (not horizontally or retro-posteriorly as in other groups), with 2 distinct outgrowths, ventral $(O v)$ and retrolateral $(\mathrm{Or})$. Embolus long and thin, lacking an accompanying membrane, tip unmodified.

Epigyne. Septum large, pentagonal, covering entire fovea, widest posteriorly or mesally, stalk of septum $(E s)$ short, with a more-or-less distinct pair of hoods $(E h)$; anterior margin of fovea either triangular (A. cursor and A. pentheri), trapezoidal, or rounded (A. cursorioides and A. etrusca); endogyne with one pair of globular receptacles, copulatory ducts cylindrical, 2-3 times thinner than receptacles; ducts either parallel (A. pentheri) or converging (A. cursor and $A$. cursorioides); receptacles with warts $(W r)$ covered with glands $(W g)$.

RELATIONSHIPS. Morphology of the epigyne indicates that cursor group is most closely related to the striatipes group. The shape of the septum in the cursor group and in some species of the striatipes group, i.e. A. cronebergi (Thorell, 1875) and A. striatipes (C.L. Koch, 1839), is very similar, but species in the latter group have 2 pairs of receptacles. Other species and species groups of Alopecosa have a well-developed stalk of the septum, sometimes longer than base of the septum, and the septum does not cover the fovea.

\section{Species survey}

Alopecosa cursor (Hahn, 1831)

Figs 1A-C, 2A, 3A-B, 4A-B, 5A-F, 7A-B, 8A, $10-12$.

Lycosa cursor Hahn, 1831: 17, f. 14 ( $\left.{ }^{7}+\right)$.

Lycosa sabulosa Hahn, 1831: 16, f. 13 ( ('0).

Alopecosa cursor: Lugetti, Tongiorgi, 1969: 52, f. 14a-g ( $\left.\sigma^{7}+\right)$; Fuhn, Niculescu-Burlacu, 1971: 150, f. 70a-e ( $\left.\sigma^{7}+\right)$; Almquist, 2005: 190, f. 192a-f ( $\left.\sigma^{\top}+\right)$.

For a complete list of references, see WSC [2018]. This species has only one synonym, listed above, although it has been considered in four different genera: Tarantula, Tarentula, Hogna, and Lycosa.

MATERIAL EXAMINED. UKRAINE: $70^{7} \sigma^{7} 2001$ juv. (TNU), Kherson area, Askania-Nova Reserve, steppe, $46^{\circ} 27^{\prime} 32^{\prime \prime} \mathrm{N}$ 3352'29"E, 23.04.2011 (A.N.). Crimea: 2 O $^{\top} \sigma^{\top} 2$ OO (TNU 10063 1, 10106-2/1), Chernomorskiy Distr., Tarkhankut Peninsula, steppe

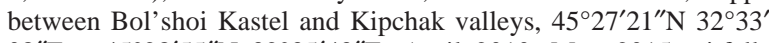
$08^{\prime \prime} \mathrm{E}-45^{\circ} 28^{\prime} 55^{\prime \prime} \mathrm{N} 32^{\circ} 35^{\prime} 43^{\prime \prime} \mathrm{E}$, April 2010, May 2015, pitfalls (V.V. Shaporinsky, A.N.); $79 \sigma^{\top} \sigma^{7} 21$ 우 (TNU SO-17/1, 20, 21, 29/2, 30/2, 31, 43/2, 55/4, 65/2, 66/2, 67/1, 68/2, 69, 77/1), Dzhankoi Distr., env. Solenoe Ozero Vill., steppe and saline lands, $45^{\circ} 56^{\prime} 14^{\prime \prime} \mathrm{N} 34^{\circ} 26^{\prime} 48^{\prime \prime} \mathrm{E}-4^{\circ} 55^{\prime} 15^{\prime \prime} \mathrm{N} 34^{\circ} 29^{\prime} 19^{\prime \prime} \mathrm{E}$, April-June

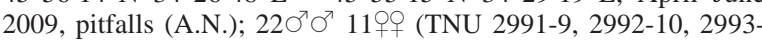
14, 2995-8, 2996-6), Feodosiya Distr., Karadag Nature Reserve, Magnitnyi Ridge, $44^{\circ} 55^{\prime} 55.3^{\prime \prime} \mathrm{N} 35^{\circ} 14^{\prime} 22.4^{\prime \prime} \mathrm{E}, 353 \mathrm{~m}$, stony steppe,
April-July 2008, pitfalls (M.K., A.N.); $1 \sigma^{7} 19$ (TNU), Simferopol,

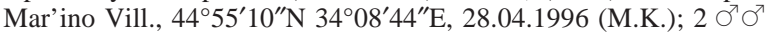
(TNU 963-10/1), Simferopol Distr., env. Lozovoe Vill., N side of quarry, Bairakly Mt. W slope, meadow, 44 $54^{\prime} 59.1^{\prime \prime} \mathrm{N} 34^{\circ} 10^{\prime}$

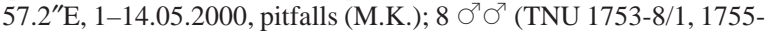
6/1, 1786-5/1, 1854-19/1), Simferopol Distr., env. Skvortsovo Vill., steppe, $45^{\circ} 04^{\prime} 57^{\prime \prime} \mathrm{N} 33^{\circ} 49^{\prime} 48^{\prime \prime} \mathrm{E}$, April-May 2002, pitfalls (M.K.); $1 \sigma^{7}$ (TNU 2443-2), Yalta Distr., Ai-Petri yaila, $1.5 \mathrm{~km} \mathrm{~W}$ tourist center, $44^{\circ} 28^{\prime} \mathrm{N} 34^{\circ} 03^{\prime} \mathrm{E}, 11-12.06 .2005$ (E.Yu. Sviridenko). RUSSIA: $2 \sigma^{7} \sigma^{7} 19$ (ZMMU), Saratov area, Krasnokut Dist., Dyakovka Vill., 50 $43^{\prime} 59.8^{\prime \prime} \mathrm{N} 46^{\circ} 46^{\prime} 31.2^{\prime \prime} \mathrm{E}$, sand mine, 28.04.2017 (O.L. Makarova); Novosibirsk area: 2 Oㅇ (ISEA 001.1335), Karasuk Distr., c. 10-12 km W of Karasuk, $53^{\circ} 43^{\prime} \mathrm{N}, 7^{\circ} 50^{\prime} \mathrm{E}$, saline steppe, 6.07.1973 (T.V. Lobanova); 4 우 (ISEA, 001.7878), c. $12 \mathrm{~km} \mathrm{~W}$ of Karasuk, 53 $43^{\prime} \mathrm{N}, 77^{\circ} 50^{\prime} \mathrm{E}$, steppe, by hand, 3.05.2002 (G.N. Azarkina, S.N. Panteleeva); $2 \sigma^{7} \sigma^{7}$ (ISEA 001.5544), c. $10 \mathrm{~km} \mathrm{~W}$ of Karasuk, 53 $43^{\prime} \mathrm{N}, 77^{\circ} 51^{\prime} \mathrm{E}$, steppe, pitfall traps, 15.05.2001 (G.N. Azarkina); 4 O$^{7} 0^{7} 5$ 우 (ISEA 001.5545), Karasuk Distr., c. 0.5 km $\mathrm{NE}$ of Troitskoe, c. $53^{\circ} 43^{\prime} \mathrm{N}, 77^{\circ} 50^{\prime} \mathrm{E}$, steppe, pitfall traps, 30.04 . 2002 (G.N. Azarkina); 1 (ISEA 001.6051), Karasuk Distr., c. 5 $\mathrm{km} \mathrm{W}$ of Troitskoe, S bank of Maloe Solyonoe Lake, c. $53^{\circ} 43^{\prime} \mathrm{N}$, 77² $2^{\prime} \mathrm{E}$, meadow steppe, 27.06.2011 (I.V. Fyodorov); $1 \sigma^{\top}$ (ISEA), Krasnozyorsk Distr., near Polovinnoe Vill., c. $53^{\circ} 43^{\prime} \mathrm{N}, 7^{\circ} 15^{\prime} \mathrm{E}$, pitfall traps, 13-20.06.2018 (A. Bashchuk); 2 오 (ISEA 001.6794) Novosibirsk, S exposition of ravine, burned grass, 12.06. 1971 (T.V. Lobanova); 1 (ISEA 001.7001), Cherepanovo District, nr Cherepanovo, c. $54^{\circ} 13^{\prime} \mathrm{N}, 83^{\circ} 21^{\prime} \mathrm{E}, 2010$ (L.A. Alekseeva); 3 우

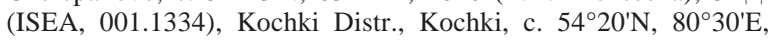
steppe meadow, 1.07.1974 (T.V. Lobanova). AZERBAIJAN: Zuvand area: $80^{7} \sigma^{7} 2$ 우 (ZMMU), Lerik Distr., Pirasora, 38 $43^{\prime}$ $18^{\prime \prime} \mathrm{N} 48^{\circ} 22^{\prime} 48^{\prime \prime} \mathrm{E}, 2000 \mathrm{~m}, 26.05 .2003$ (Yu.M. Marusik \& E.F. Huseynov); $3 \sigma^{7} \sigma^{7}$ (ZMMU), ca $3 \mathrm{~km} \mathrm{~W}$ of Lerik Town, $38^{\circ} 43^{\prime} 50^{\prime \prime} \mathrm{N}$ $48^{\circ} 25^{\prime} 40^{\prime \prime} \mathrm{E}, 1200 \mathrm{~m}$, sloppy meadows, 25.05.2003 (Yu.M. Marusik); $1 \sigma^{7}$ (ZMMU), Nakhchivan, env. of Bichenek Vill.,

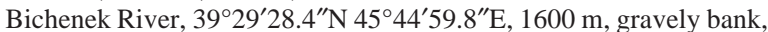
3.06.2003 (Yu.M. Marusik). KYRGYZSTAN: $3 \sigma^{7} \sigma^{7} 1$ (ZMMU),

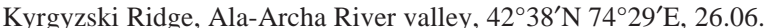
1993 (S.V. Ovchinnikov). CHINA: Xinjiang: 1 (ZMMU), Nantaizi, $43^{\circ} 23^{\prime} 56.4^{\prime \prime} \mathrm{N} 87^{\circ} 12^{\prime} 50.4^{\prime \prime} \mathrm{E}-43^{\circ} 25^{\prime} 48^{\prime \prime} \mathrm{N} 87^{\circ} 15^{\prime} 18^{\prime \prime} \mathrm{E}, 1800$ 2100 m, meadow slopes, 2.06.2004 (N.R. Fritzén); $2 \sigma^{7} \sigma^{7}$ (ZMUT), Minoergou, 43⒉ $29^{\prime} 46.3^{\prime \prime} \mathrm{N} 86^{\circ} 53^{\prime} 49.9^{\prime \prime} \mathrm{E}, 2000-2200 \mathrm{~m}, 16.05 .2004$ (N.R. Fritzén).

DIAGNOSIS. Alopecosa cursor is most similar to $A$. pentheri, a species with which it occurs sympatrically in many localities. Males of the two species are easily distinguished by the venter of the abdomen: A. cursor is lacking short, spine like setae that are present in A. pentheri (cf. Figs $1 \mathrm{C}, 1 \mathrm{H}, 1 \mathrm{~J}-\mathrm{K}, 6 \mathrm{I}-\mathrm{J})$. Additionally, males can be separated by the size of the palp (cf. Figs $2 \mathrm{~A}-\mathrm{B}$ ), shape of the tegular apophysis, and embolus. Alopecosa cursor has widely spaced ventral $(O v)$ and retrolateral outgrowths $(\mathrm{Or})$ of the tegular apophysis, whereas these outgrowths are closely spaced in A. pentheri (cf. Figs 2A-B, 3A, 3C). In addition, A. cursor has a relatively thinner embolus, with the median part 3 times wider than the tip, whereas in A. pentheri, it is 5 times wider than the tip (cf. Figs $5 \mathrm{~F}, 5 \mathrm{~L}$ ).

The females of the two species are nearly indistinguishable due to variation of the septum and receptacles. The two species can be separated by the carapace length / femur I length ratio (cf. Fig. 10). 

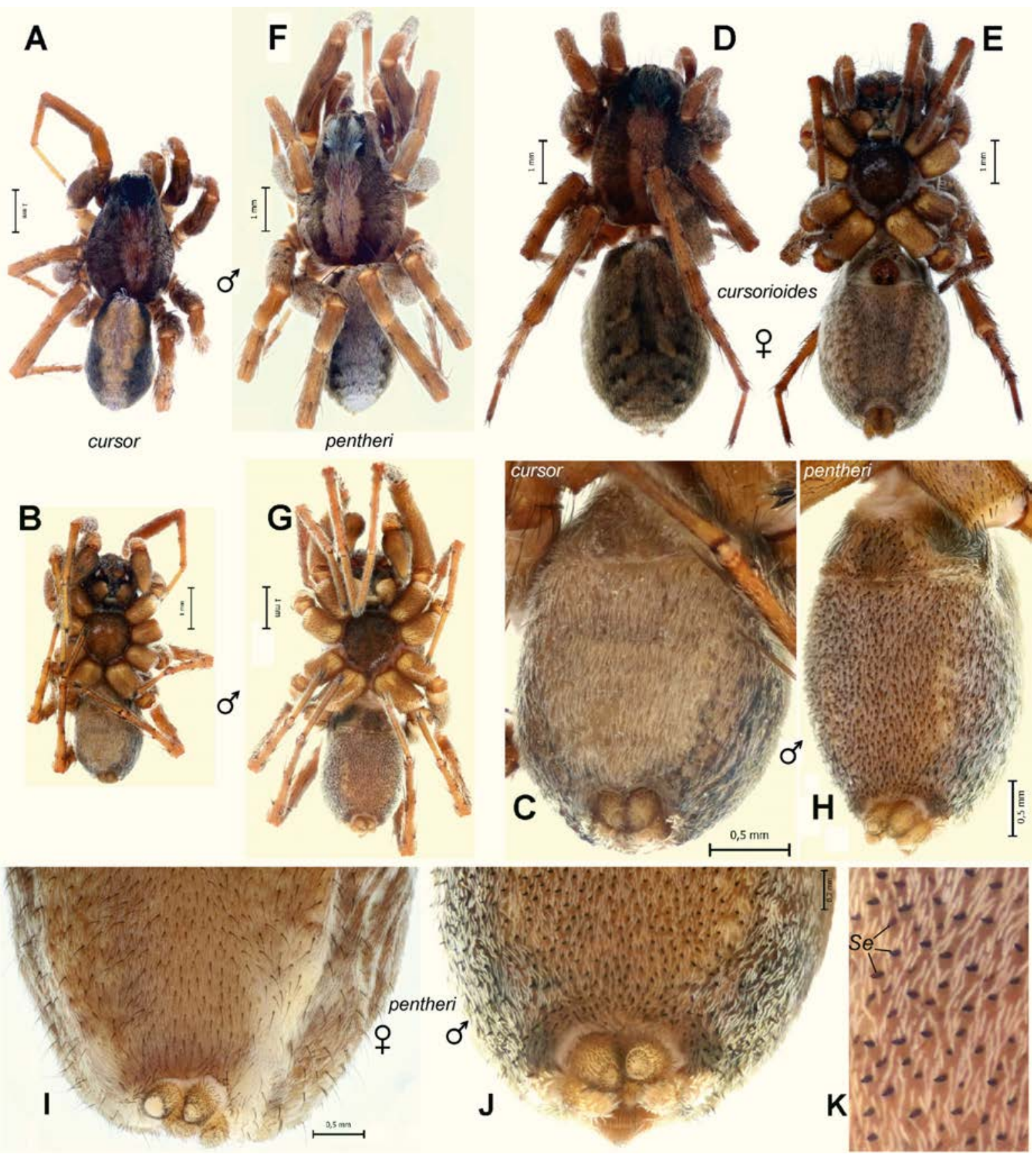

Fig. 1. Habitus of Alopecosa cursor (A-C) from Azerbaijan, A. cursorioides (D-E) from Uzbekistan, and A. pentheri (F-K) from Crimea. A, F - male body, dorsal; B, G - male body, ventral; D, E - female body, dorsal and ventral; C, H - male abdomen, ventral; I$\mathrm{J}$ - female and male posterior half of abdomen, ventral; K — fragment of male abdomen, ventral. Abbreviation: Se — short spine like setae on the venter of abdomen.

Pис. 1. Габитус Alopecosa cursor (A-C) из Азербайджана, A. cursorioides (D-E) из Узбекистана и A. pentheri (F-K) из Крыма. A, F - самец, дорзально; В, G - самец, вентрально; D, E - самка, дорзально и вентрально; C, Н - брюшко самца, вентрально; I-J - задняя часть брюшка самки и самца, вентрально; K - фрагмент брюшка самца, вентрально. Обозначения: $S e$ - короткие шипообразные щетинки на вентральной стороне брюшка.

DESCRIPTION. $\sigma^{7}+$ from Azerbaijan.

Male: total length 6.35; carapace 3.5 long, 2.5 wide; leg length (Table 1a): I 7.72 (2.12, 1.12, 1.6, 1.68, 1.2); II 7.29 (2.02, 1.04, 1.45, 1.66, 1.12); III 7.33 (2.0, 1.0, 1.4, 1.88, 1.05); IV $9.75(2.6,1.15,1.9,2.78,1.32)$.

Palp as in Figs 2A, 3A-B, 4A-B, 5A-F: sperm duct with almost straight course; prolateral tip of tegulum $(T t)$ not hidden by embolus (Figs 2A, 3A, 5A); terminal part of tegular apophysis wider than mesal part, anterior edge of tegular apophysis $(A t)$ rounded, outgrowths widely separated (Fig. 3A) and forming a right angle in anterior view (Fig. 3B), embolus relatively short. 

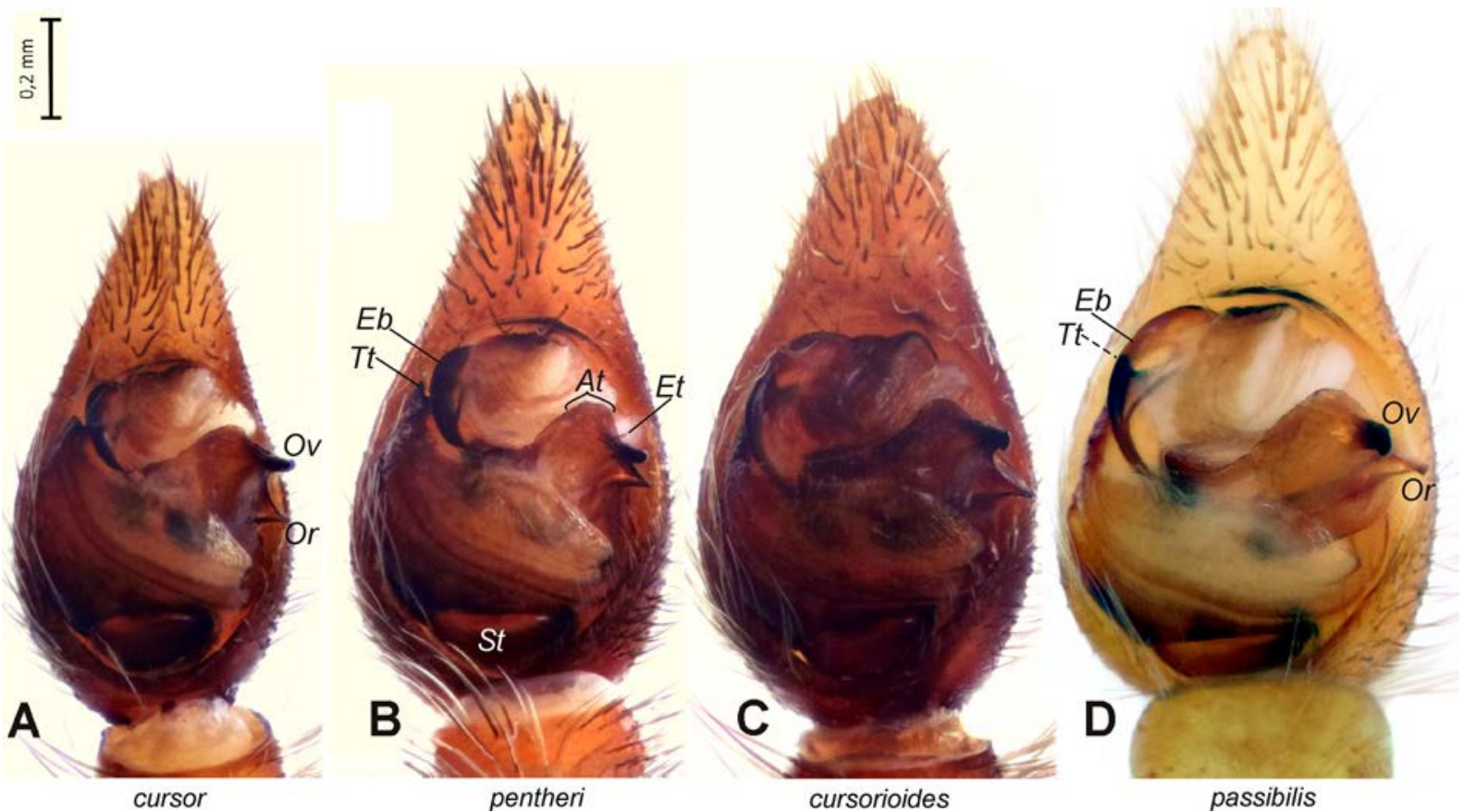

Fig. 2. Male palps of Alopecosa cursor (A) from Azerbaijan, A. pentheri (B) from Crimea, A. cursorioides (C) from Uzbekistan, and paralectotype of A. passibilis (D). Ventral. Abbreviations: At — anterior edge of tegular apophysis; Eb,Et — base and tip of embolus; Or, $O v$ - retrolateral and ventral outgrowths of tegular apophysis; $S t$ - subtegulum; $T t$ - prolateral tip of tegulum.

Рис. 2. Пальпы самцов Alopecosa cursor (А) из Азербайджана, A. pentheri (B) из Крыма, A. cursorioides (С) из Узбекистана и паралектотипа A. passibilis (D). Вентрально. Обозначения: $A t$ - передний край тегулярного отростка; $E b, E t-$ основание и конец эмболюса; $O r, O v-$ ретролатеральная и вентральная ветви тегулярного отростка; $S t-$ субтегулюм; $T t-$ пролатеральная вершина тегулюма.
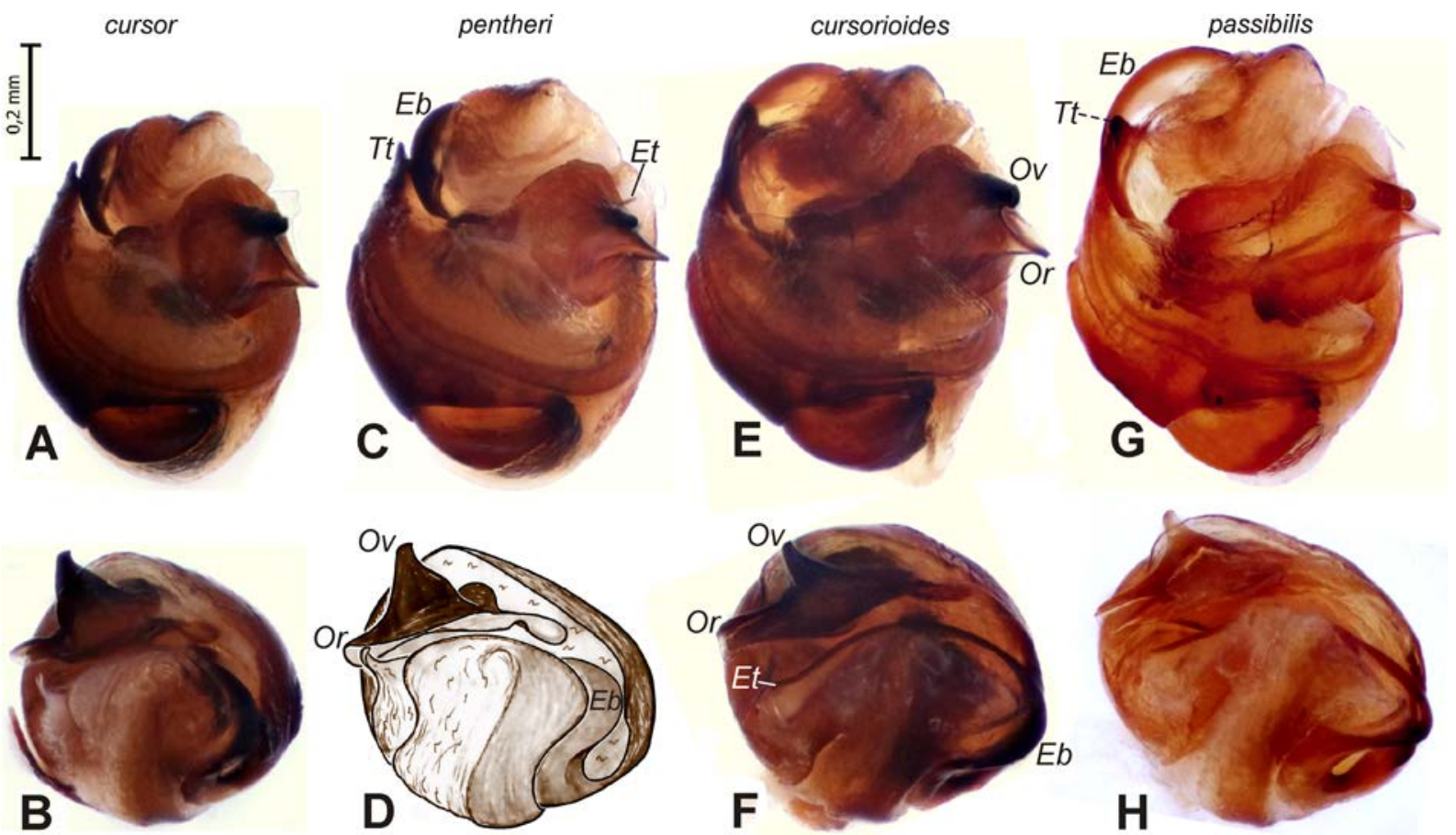

Fig. 3. Bulb of Alopecosa cursor (A-B) from Azerbaijan, A. pentheri (C-D) from Crimea, A. cursorioides (E-F) from Uzbekistan, and paralectotype of A. passibilis (G-H). A, C, E, G - ventral; B, D, F, H - anterior (=apical). Abbreviations: Eb, Et - base and tip of embolus; $O r, O v$ - retrolateral and ventral outgrowths of tegular apophysis; $T t$ - prolateral tip of tegulum.

Рис. 3. Бульбус Alopecosa cursor (A-B) из Азербайджана, A. pentheri (C-D) из Крыма, A. cursorioides (E-F) из Узбекистана и паралектотипа A. passibilis (G-H). A, C, Е, G — вентрально; В, D, F, Н — спереди (=апикально). Обозначения: Eb, Et — основание и конец эмболюса; $\mathrm{Or}, \mathrm{Ov}$ - ретролатеральная и вентральная ветви тегулярного отростка; $T t$ - пролатеральная вершина тегулюма. 

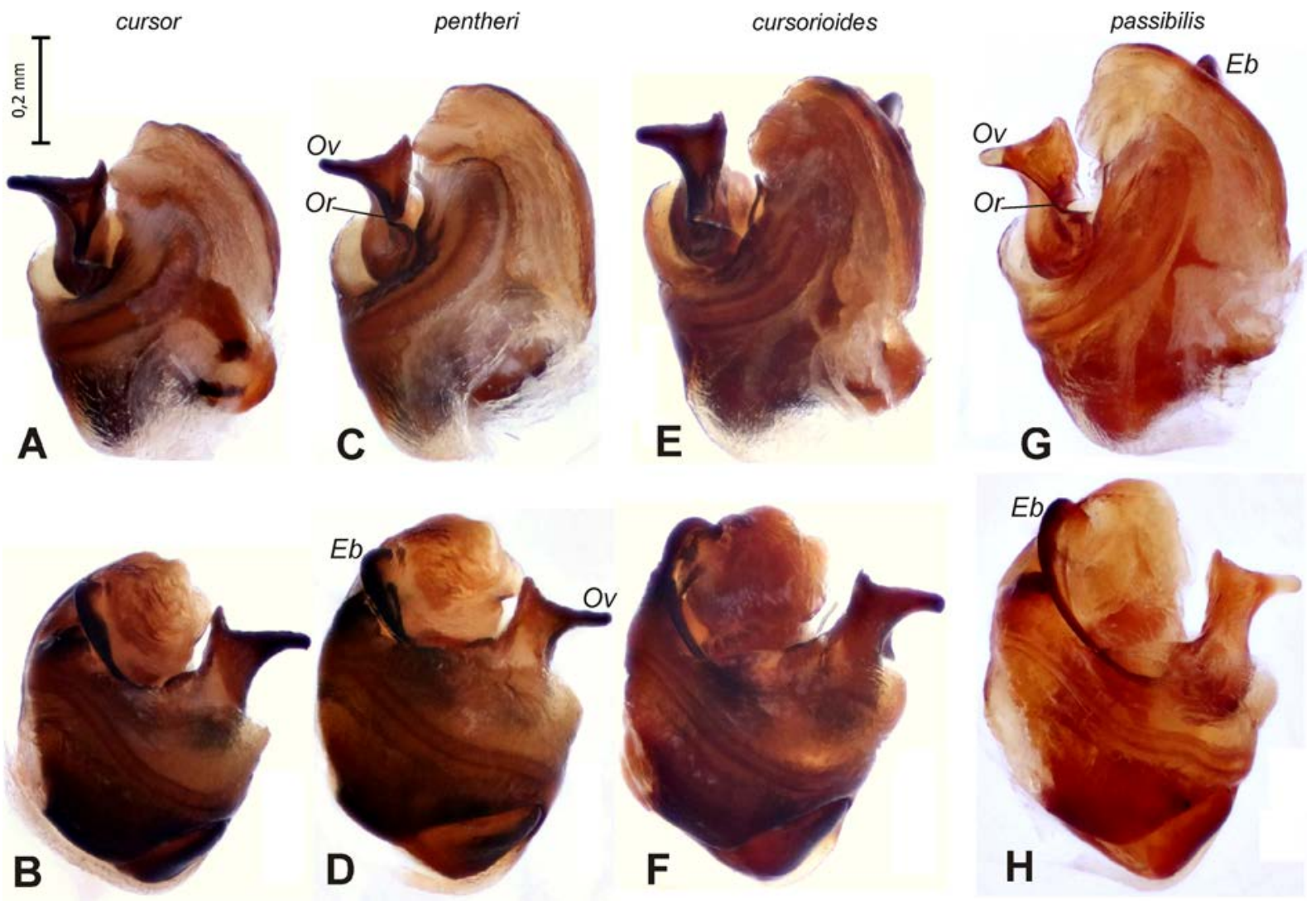

Fig. 4. Bulb of Alopecosa cursor (A-B) from Azerbaijan, A. pentheri (C-D) from Crimea, A. cursorioides (E-F) from Uzbekistan, and paralectotype of A. passibilis $(\mathrm{G}-\mathrm{H})$. A, C, E, G - retrolateral; B, D, F, H - prolateral. Abbreviations: Eb - base of embolus; Or, Ov retrolateral and ventral outgrowths of tegular apophysis.

Рис. 4. Бульбус Alopecosa cursor (A-B) из Азербайджана, A. pentheri (C-D) из Крыма, A. cursorioides (Е-F) из Узбекистана и паралектотипа A. passibilis $(\mathrm{G}-\mathrm{H})$. A, C, E, G - ретролатерально; В, D, F, Н - пролатерально. Обозначения: Eb - основание эмболюса; $\mathrm{Or}, \mathrm{Ov}$ - ретролатеральная и вентральная ветви тегулярного отростка.

Female: total length 9.0; carapace 3.75 long, 2.55 wide; leg length (Table 2a): I 7.97 (2.29, 1.2, 1.6, 1.7, 1.18); II 7.67 (2.18, 1.15, 1.5, 1.72, 1.12); III 7.76 (2.12, 1.12, 1.42, $2.0,1.1)$; IV $10.92(2.88,1.28,2.12,3.22,1.42)$.

Epigyne as in Figs 7A-B, 8A: septum as wide as long, widened posteriorly, anterior part triangular; receptacles converging, copulatory duct about 2.5 times thinner than receptacle.

Variation $\left(\$ / \bigcirc^{7}\right.$ from Crimea, $\left.\mathrm{n}=10 / 10\right)$ : total length 7.0 8.7/5.8-6.7; carapace 3.45-3.55/3.05-3.35 long, 2.5-2.7/ 2.15-2.38 wide.

COMMENTS. Alopecosa cursor and A. pentheri can be easily distinguished from the 3 other species in the group, $A$. cursorioides, A. etrusca, and A. passibilis by the following: males of A. cursor and A. pentheri have a distinct prolateral tip of the tegulum (Tt, Figs $2 \mathrm{~A}-\mathrm{B}, 3 \mathrm{~A}, 3 \mathrm{C}$ ), while in other species this tip is hidden by the base of the embolus $(E b)$ and indistinct in ventral view (Figs $2 \mathrm{C}-\mathrm{D}, 3 \mathrm{E}, 3 \mathrm{G}$ ). The septum in $A$. cursor and A. pentheri is wider posteriorly, while in other species it is wider anteriorly (cf. figs 7A-K; Lugetti, Tongiorgi, 1969: 16e). Due to these differences, the cursor group can be subdivided into 2 subgroups: cursor and passibilis.

TYPE LOCALITY. Central Europe, probably Germany [Hahn, 1831], exact type locality is not indicated, and types apparently do not exist. This species cannot be confused with others because it is a single species of the cursor group occurring in Germany [Helsdingen, 2018].

DISTRIBUTION. West Palaearctic nemoral range: known from Spain to Xinjiang and Altai, north to southern Finland and south to Greece and Kyrgyzstan [Song et al., 1999; Fomichev, 2015; Helsdingen, 2018; our data]. The record of this species from the Razavi-Khorasan Province of Iran [Mirshamsi et al., 2015] probably refers to the similar A. cursorioides. A. cursor and A. pentheri have been reported many times from the Crimea. A list of references is given in Kovblyuk [2004] and Kovblyuk \& Kastrygina [2015]. Study of the material reveals that records of A. cursor often actually refer to A. pentheri and vice versa. Alopecosa pentheri is much more common in the Crimea than A. cursor (cf. lists of material).

PHENOLOGY. In the Crimea, adult males of A. cursor can be found from April to July with a peak in April-May; adult males of $A$. pentheri are active from March to September, with a peak of activity in April-May (Fig. 12). Thus, the phenology of A. cursor and A. pentheri in Crimea are similar, but $A$. pentheri appears one month earlier and is active until autumn. Lugetti \& Tongiorgi [1969] wrote that adults of A. cursor can be found from May to July. The same pattern has been reported for the Swedish population [Almquist, 2005]. As females of $A$. cursor and A. pentheri are 

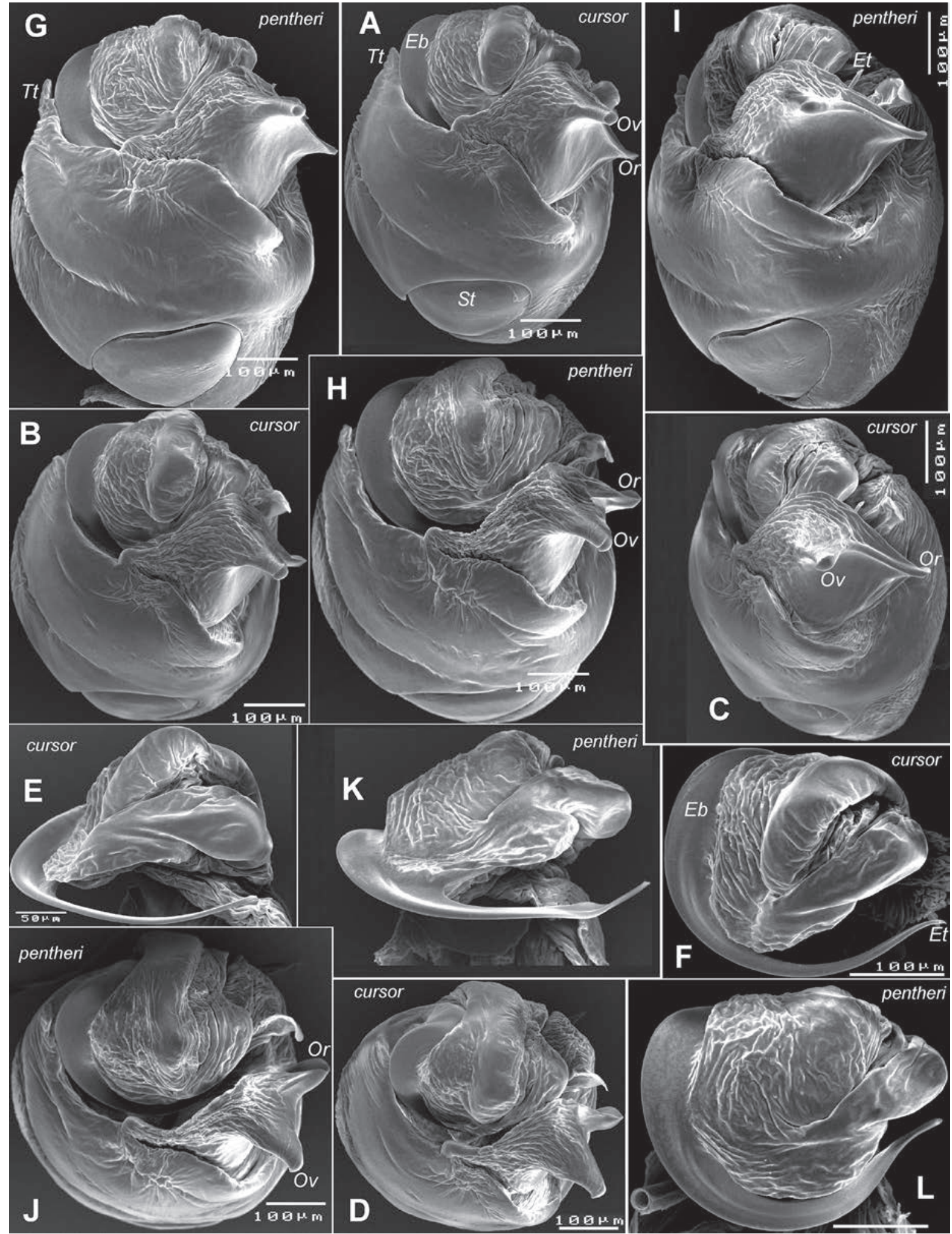

Fig. 5. SEM micrographs of bulb of Alopecosa cursor (A-F) from Azerbaijan and A. pentheri (G-L) from Crimea. A, F-G, L ventral; C, I - ventral-retrolateral; B, H - apical-ventral; D, J - apical; E, K - caudal. Abbreviations: Eb, Et - base and tip of embolus; $\mathrm{Or}, \mathrm{Ov}$ - retrolateral and ventral outgrowths of tegular apophysis; $S t$ - subtegulum; $T t$ - prolateral tip of tegulum.

Рис. 5. СЭМ-фото бульбусов Alopecosa cursor (A-F) из Азербайджана и A. pentheri (G-L) из Крыма. A, F-G, L - вентрально; C, I — вентро-ретролатерально; В, Н - спереди-вентрально; D, J — спереди; Е, К — сзади. Обозначения: $E b, E t-$ основание и конец эмболюса; $O r, O v-$ ретролатеральная и вентральная ветви тегулярного отростка; $S t-$ субтегулюм; $T t$ - пролатеральная вершина тегулюма. 
Table 3. Number of adult males per 100 pitfall-trap-days in steppe habitats where Alopecosa cursor and

A. pentheri were found to be sympatric.

Таблица 3. Количество самцов на 100 ловушко-суток в биотопах с симпатрическим обитанием Alopecosa cursor и A. pentheri.

\begin{tabular}{|l|c|c|}
\hline \multicolumn{1}{|c|}{ Locality } & A. cursor & A. pentheri \\
\hline Solenoe Ozero Vill., $\mathrm{N}^{\circ} 55^{\circ} \mathrm{E} 34^{\circ} 29^{\prime}$ (1 station) & 2.4 & 0.11 \\
\hline Skvortsovo Vill., $\mathrm{N} 45^{\circ} 05^{\prime} \mathrm{E} 33^{\circ} 50^{\prime}$ (3 stations) & $0.17-0.25$ & $2.7-7.3$ \\
\hline Lozovoe Vill., N44 $55^{\prime} \mathrm{E} 34^{\circ} 11^{\prime}$ (1 station) & 0.03 & 0.06 \\
\hline Tarkhankut Pen., $\mathrm{N} 45^{\circ} 27^{\prime} \mathrm{E} 32^{\circ} 33^{\prime}$ (1 station) & 0.08 & 6.9 \\
\hline
\end{tabular}

almost indistinguishable, they weren't used for the analysis of the phenology, but only males.

HABITATS. In the Crimea, A. cursor occurs from sea level to $1000 \mathrm{~m}$ and inhabits saline lands (with Salicornia, Halocnemum, Phragmites, Carex), semi-deserts, true steppes (with Festuca, Stipa, Artemisia), and mountain meadows. In the Crimea and Azerbaijan, A. cursor and A. pentheri are often found to be sympatric, and both of these species have been collected by the same traps simultaneously although in different abundance (Table 3). Alopecosa cursor was found to be more common in semi-desert steppes (Solenoe Ozero Vill.), while A. pentheri is more abundant in true steppes (Skvortsovo Vill. and Tarkhankut Peninsula). In some parts of the Crimea (Karadag Nature Reserve), these species are found in the same locality but in different habitats: A. pentheri is found in all parts of the reserve except the steppe on the Magnitnyi Ridge, while A. cursor is found only in the steppe on the Magnitnyi Ridge. The distribution and relative abundance of the two sibling species in the Crimea are shown in Fig. 11. In Italy A. cursor occurs up to $1000 \mathrm{~m}$ [Lugetti, Tongiorgi, 1969].

Alopecosa cursorioides Charitonov, 1969 stat.n. Figs 1D-E, 2C, 3E-F, 4E-F, 6A-D, 7C-G, 8D-E, $9 \mathrm{~A}-\mathrm{C}$. $\left(\sigma^{\top}+\right)^{2}$

Alopecosa cursor cursorioides Charitonov, 1969: 91, f. 6-7

This species has a single taxonomic entry.

MATERIAL EXAMINED. TURKMENISTAN: $1 \sigma^{7}$ (ZMMU), E Kopetdagh, Miana-Chaacha, 36 ${ }^{\circ} 52^{\prime} \mathrm{N}$ 60²3'E, 22-28.04.1978 (G.T. Kuznetsov); $3 \sigma^{7} \sigma^{\top} 2$ 우 (ZMMU), Kopetdagh Mt., Bakharden, $38^{\circ} 24^{\prime} \mathrm{N} 57^{\circ} 21^{\prime} \mathrm{E}, 5.05 .1993$ (S.V. Ovtchinnikov). UZBEKISTAN: 2 우 (ZMMU), Babatagh Ridge, Kafirnighan River valley, $38^{\circ} 00^{\prime} \mathrm{N} 68^{\circ} 17^{\prime} \mathrm{E}, 25.04 .1994$ (S.V. Ovtchinnikov); 2 ○ $^{\top} \sigma^{\top} 2$ 우 (ZMMU), Babatagh Ridge, Ak-Mechet, $38^{\circ} 01^{\prime} \mathrm{N} 68^{\circ} 17^{\prime} \mathrm{E}, 26.04$ 1994 (S.V. Ovtchinnikov)

DIAGNOSIS. Alopecosa cursorioides is closely related to A. passibilis. Males of the two species differ by the size and shape of the bulb. The palp of $A$. cursorioides is smaller (cf. Fig. 2C-D) than that of A. passibilis. The two outgrowths of the tegular apophysis are separated by 2.5 widths of the ventral outgrowth, while in A. passibilis they are not separated (cf. Figs 2C-D, 3E, G). Females of A. cursorioides are similar to those of $A$. etrusca by having the septum wider anteriorly ( $v s$. posteriorly in other species), but in $A$. cursorioides the septum is wider than in A. etrusca (cf. Figs 7C-G; Lugetti, Tongiorgi, 1969: fig. 16e).

DESCRIPTION. $\sigma^{7} \rightarrow$ from Uzbekistan

Male: total length 6.25; carapace 3.25 long, 2.35 wide; legs length (Table 3a): I $8.28(2.29,1.12,1.75,1.9,1.22)$; II $7.88(2.18,1.14,1.62,1.82,1.12)$; III 7.87 (2.12, 1.02, 1.55, $2.1,1.08)$; IV $10.66(2.85,1.22,2.2,3.0,1.39)$.
Palp as in Figs 2C, 3E-F, 4E-F, 6A-D: sperm duct straight and almost horizontal near posterior edge of tegulum; prolateral tip of tegulum (Tt) hidden by embolus (Figs $2 \mathrm{C}, 3 \mathrm{E}, 6 \mathrm{~A})$; terminal part of tegular apophysis as wide as mesal part, outgrowths well separated (Figs 2C, 3E), ventral outgrowth shorter than retrolateral (Fig. 3F), both outgrowth forms appear as right angles in anterior view; embolus relatively long.

Female: total length 8.45 ; carapace 3.7 long, 2.5 wide; legs length (Table 4a): I 7.79 (2.25, 1.12, 1.65, 1.65, 1.12); II $7.42(2.12,1.12,1.48,1.62,1.08)$; III $7.47(2.08,1.02$, $1.4,1.92,1.05)$; IV $10.66(2.78,1.25,2.11,3.1,1.42)$.

Epigyne as in Figs 7C-G, 8D-E, 9A-C: septum as wide as long or its width is slightly more than the length, widened anteriorly, anterior part trapezoidal $(7 \mathrm{E})$ or rounded $(7 \mathrm{~F}-\mathrm{G})$; receptacles converging, copulatory duct about 2.5 times thinner than receptacle.

COMMENTS. This species was described as a subspecies of $A$. cursor but should be considered a separate species based on the clear differences in the shape of the male palp and the epigyne.

TYPE LOCALITY. This species was described based on a series of 14 males, 6 females, and 5 juveniles collected in three localities: environs of Tashkent, Yakkabagh, and Yangikishlak. Because no holotype was designated and the syntypes are apparently lost (Esyunin, pers. comm.), we cannot designate the lectotype and type locality.

DISTRIBUTION. Turkmenistan (new country record) and Uzbekistan [Charitonov, 1969]. The record of A. cursor from Razavi Khorasan (Northeastern Iran) by Mirshamsi et al. [2015], an area adjacent to Turkmenistan, most likely refers to this species.

\section{Alopecosa passibilis (O. Pickard-Cambridge, 1885), comb.n.}

Figs 2D, 3G-H, 4G-H, 6E-H.

Lycosa passibilis O. Pickard-Cambridge, 1885: $92\left(\mathrm{O}^{7}\right)$.

Pardosa passibilis: Schmidt, 1895: 475 (described $q$ from Kyrgyzstan, most likely refers to A. cursor).

Pardosops passibilis: Roewer, 1955: 197.

TYPE MATERIAL: (OUMNH): vial "faded label, 1700" lectotype $\sigma^{7}$; vial "faded label, 1700" — paralectotype $\sigma^{7}$.

NOTE. Material collected during the Second Yarkand Mission and described by O. Pickard-Cambridge [1885] contains no geographical and no species labels, just the bottle and vial numbers.

TYPE LOCALITY. Indicated in the text as "Hills between Sirikol and Aktalla, between the 8th and 18th of May 1874 ". 


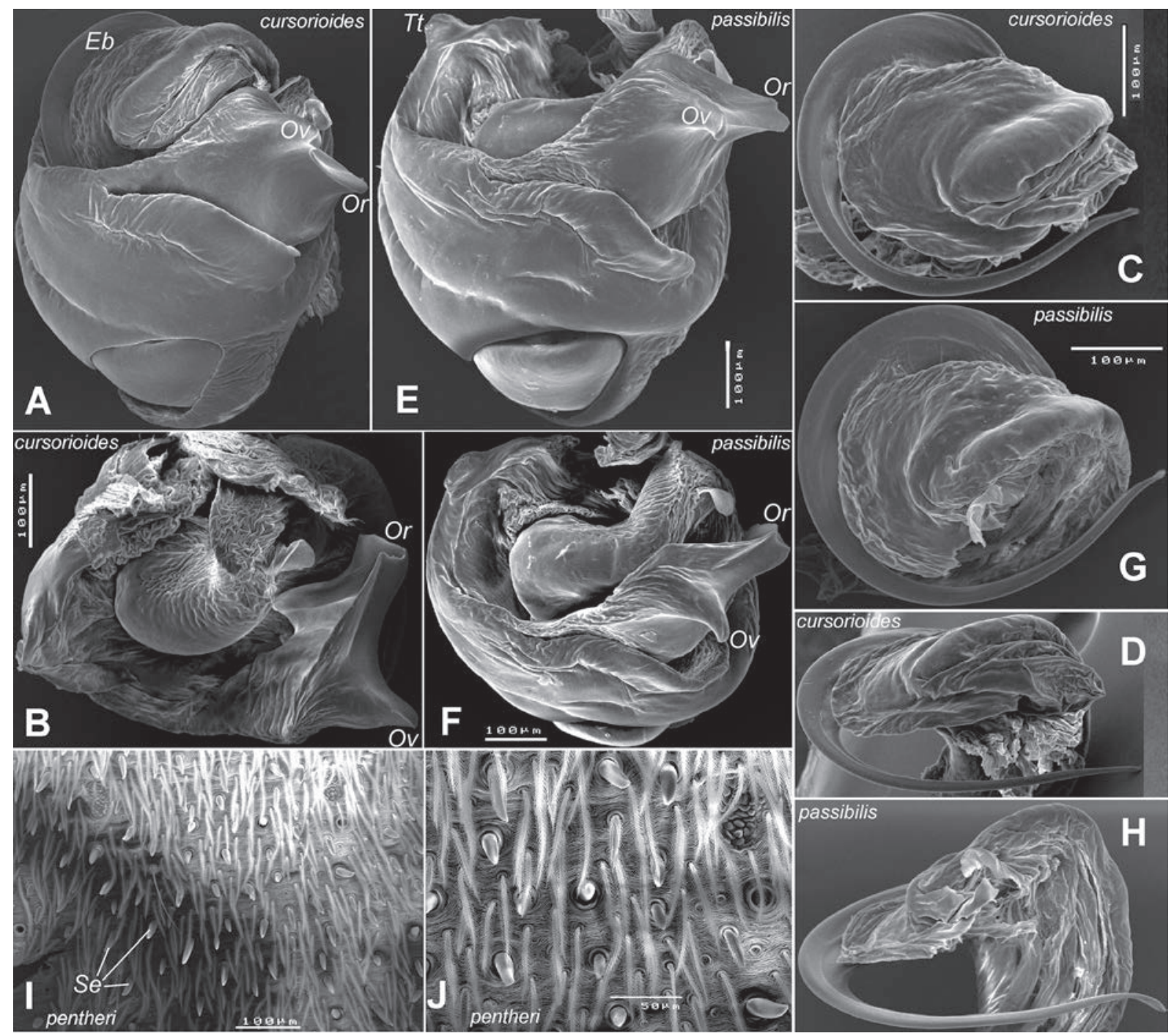

Fig. 6. SEM micrographs of bulb of Alopecosa cursorioides (A-D) from Uzbekistan and paralectotype of A. passibilis (E-H), and fragment of male abdominal cuticula of A. pentheri (I-J) from Crimea. A, C, E, G, I-J - ventral; B, F - apical; D, H - caudal. Abbreviations: $E b$ - base of embolus; $O r, O v$ - retrolateral and ventral outgrowths of tegular apophysis; Se — short spine like setae on the venter of abdomen; $T t$ - prolateral tip of tegulum.

Рис. 6. СЭМ-фото бульбусов Alopecosa cursorioides (A-D) из Узбекистана и паралектотипа A. passibilis (E-H), и фрагмент кутикулы брюшка самца A. pentheri (I-J) из Крыма. А, С, E, G, I-J - вентрально; В, F - спереди; D, H - сзади. Обозначения: $E b-$ основание эмболюса; $\mathrm{Or}, \mathrm{Ov}-$ ретролатеральная и вентральная ветви тегулярного отростка; $\mathrm{Se}-$ короткие шипообразные щетинки на вентральной стороне брюшка; $T t$ - пролатеральная вершина тегулюма.

DESCRIPTION. Male measurements: total length 6.25; carapace 3.8 long, 2.6 wide; leg I length (Table 5a): 9.6 $(2.58,1.32,2.0,2.2,1.5)$.

Palp as in Figs 2D, 3G-H, 4G-H, 6E-H: sperm duct with almost straight course; prolateral tip of tegulum $(T t)$ hidden by embolus (Figs 2D, 3G); terminal part of tegular apophysis wider than mesal part, anterior edge of tegular apophysis $(A t)$ smoothly rounded, outgrowths closely spaced in ventral view (Figs 2D, 3G), retrolateral outgrowth longer than ventral one (anterior view), both united by smooth, rounded lamella (Fig. 3G-H), embolus relatively long.

Female unknown.

COMMENTS. It is easy to recognize this species among numerous unlabeled types of Lycosidae from the Second
Yarkand Mission due to the indication in O. Pickard-Cambridge's text [1885] that only the male is known, and its size is "slightly over than 3 lines" ( $6.4 \mathrm{~mm})$. It is worth noting that $A$. pentheri, a species belonging to the A. cursor group, was originally placed in Pardosa [Nosek, 1905] like $A$. passibilis.

DISTRIBUTION. The World Spider Catalog [2018] indicates the distribution as Kyrgyzstan, although it was described from SW Xinjiang, China based on syntypes males. Schmidt [1895] reported this species based on females (still unknown yet) from Alai Mountain Range, lying in the border between Kyrgyzstan and Tajikistan, this may refer to $A$. cursor, a species known from Kyrgyzstan. 

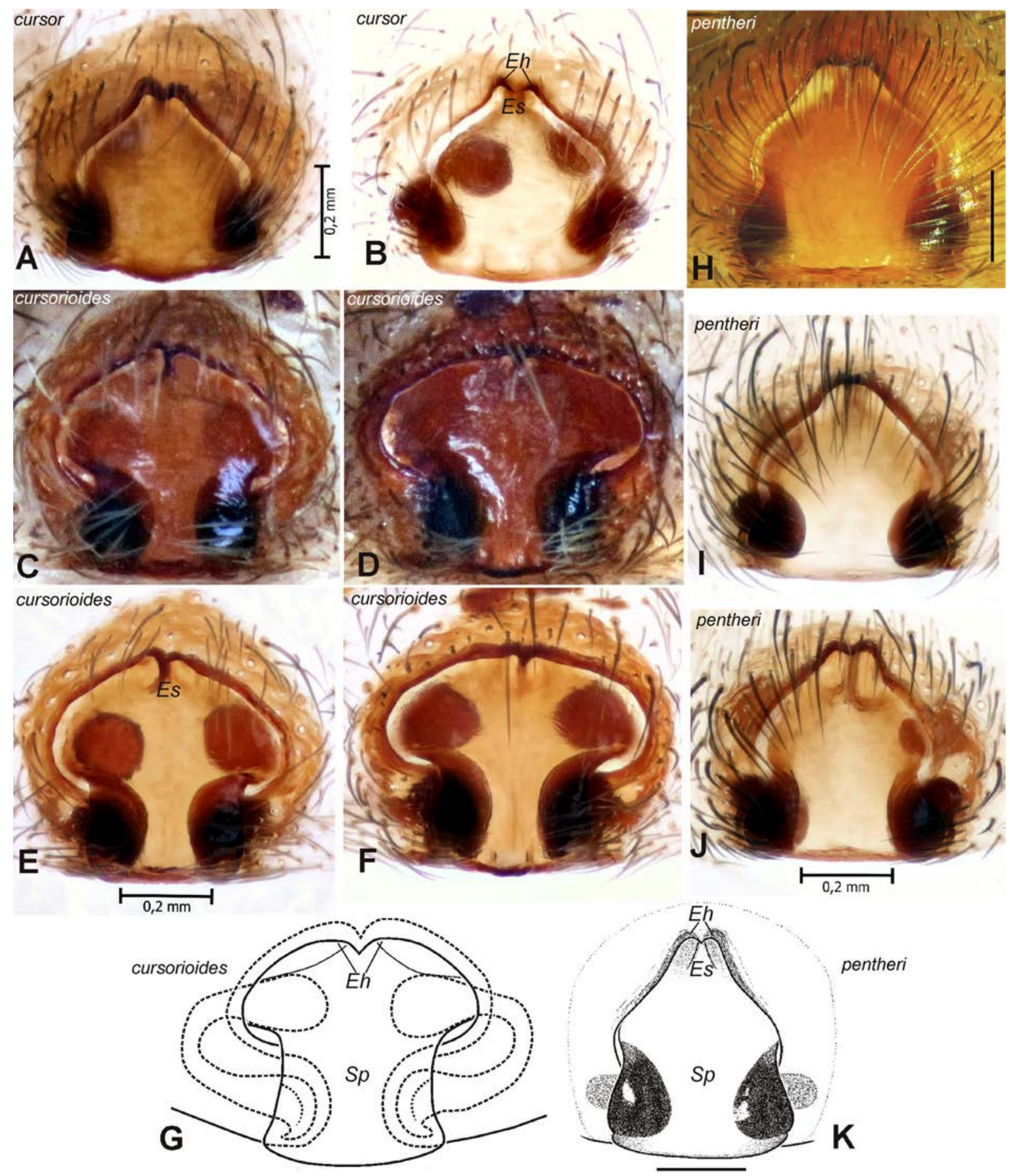

Fig. 7. Epigyne of Alopecosa cursor (A-B) from Azerbaijan, A. cursorioides (C-G) from Uzbekistan, and A. pentheri (H-K) from Crimea. Ventral. Abbreviations: $E h$ - hoods of epigyne; $E s$ - stalk of septum; $S p$ - septum of epigyne. G after Charitonov [1969].

Рис. 7. Эпигина Alopecosa cursor (A-B) из Азербайджана, A. cursorioides $(\mathrm{C}-\mathrm{G})$ из Узбекистана и A. pentheri $(\mathrm{H}-\mathrm{K})$ из Крыма. Вентрально. Обозначения: $E h$ - карманы эпигины; $E s$ - ножка септума; $S p$ - септум эпигины. G - по: Charitonov [1969]. 

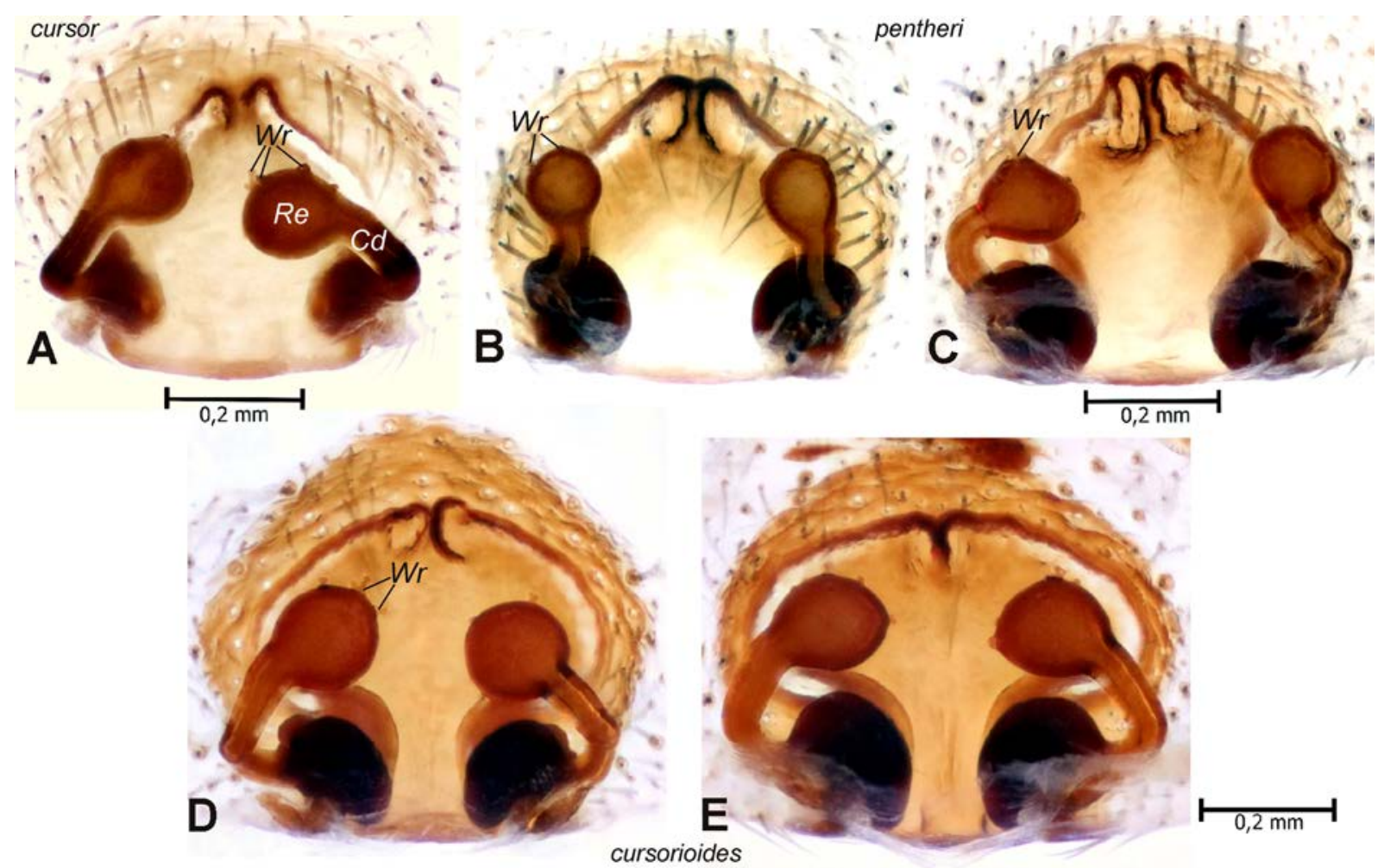

Fig. 8. Epigyne of Alopecosa cursor (A) from Azerbaijan, A. pentheri (B-C) from Crimea, and A. cursorioides (D-E) from Uzbekistan. Dorsal. Abbreviations: $\mathrm{Cd}$ - copulatory duct; $\mathrm{Re}$ - receptacle; $\mathrm{Wr}$ - warts of receptacle.

Рис. 8. Эпигина Alopecosa cursor (A) из Азербайджана, A. pentheri (B-C) из Крыма и A. cursorioides (D-E) из Узбекистана. Дорзально. Обозначения: $C d-$ копулятивный канал; $R e-$ сперматека; $W r-$ бородавки сперматеки.
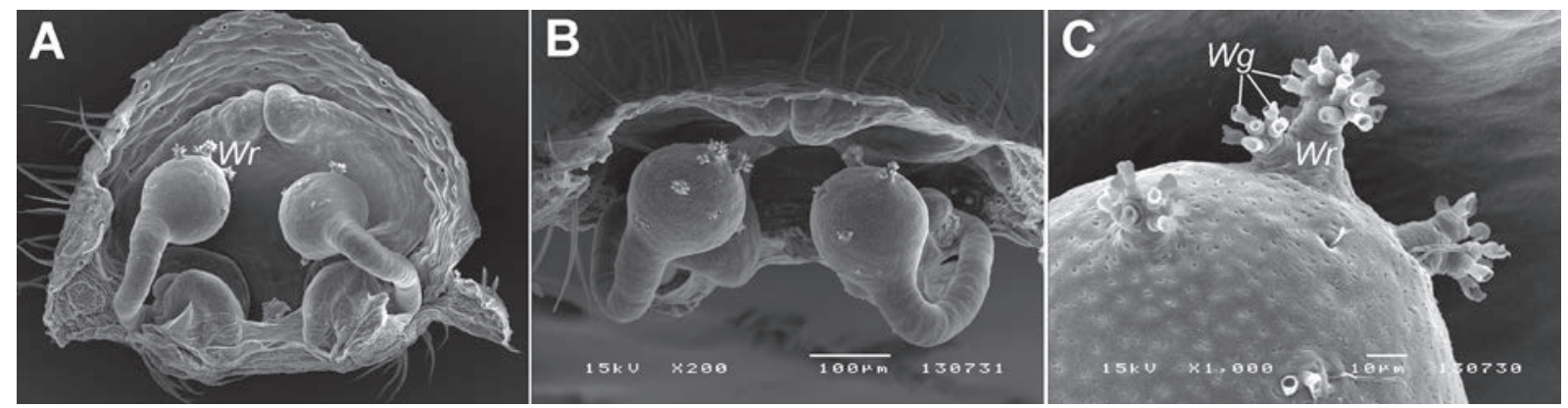

Fig. 9. SEM micrographs of epigyne of Alopecosa cursorioides from Uzbekistan. A - ventral; B — anterior; C - anterior part of receptacle. Abbreviations: warts of receptacles $(\mathrm{Wr})$ covered with glands $(\mathrm{Wg})$.

Рис. 9. СЭМ-фото эпигины Alopecosa cursorioides из Узбекистана. А - вентрально; В - спереди; С - передняя часть сперматеки. Обозначения: бородавки сперматеки $(W r)$ увенчанные железами $(W g)$.

Alopecosa pentheri (Nosek, 1905)

Figs $1 \mathrm{~F}-\mathrm{K}, 2 \mathrm{~B}, 3 \mathrm{C}-\mathrm{D}, 4 \mathrm{C}-\mathrm{D}, 5 \mathrm{G}-\mathrm{L}, 6 \mathrm{I}-\mathrm{J}, 7 \mathrm{H}-\mathrm{K}$,

$$
8 \mathrm{~B}-\mathrm{C}, 10-12 \text {. }
$$

Pardosa pentheri Nosek, 1905: 141, f. 21, 24 (Ơ⿱ + ).

Lycosa cursor insignis Nosek, 1905: 138 ().

Lycosa cursor dordeiae Strand, 1917: 72 (new name for $L$. c insignis thought to be homonym of Trochosa insignis O. PickardCambridge, 1898)

Tarentula cursor elatior Kratochvil, 1935: 19, f. 14 ().

Pardosella pentheri: Roewer, 1955: 196.

Alopecosa cursor elatior: Roewer, 1955: 216.

Alopecosa cursor insignis: Roewer, 1955: 216.
Alopecosa pentheri: Tongiorgi, 1966: 339 ( $0^{7}+$ transferred from Pardosa); Dunin, 1984: 47, f. 3 (9); Thaler et al., 2000: 1073, f. 3-4, 42, 46-47 (O'+

Alopecosa cursor pentheri: Lugetti, Tongiorgi, 1969: 55, f. $15 \mathrm{a}-\mathrm{c}\left(\mathrm{O}^{\mathrm{T}}\right)$.

Alopecosa insignis: Lugetti, Tongiorgi, 1969: 57, f. 15d-e ( + , elevated from subspecies of $A$. cursor).

MATERIAL EXAMINED. UKRAINE: Kherson area: $50^{7} \sigma^{7}$ 3 우 (TNU 2895-4, 3134-1), S from Genichesk, Crimean Peninsula, Arabatskaya Strelka, env. Strelkovoe Vill., $45^{\circ} 55^{\prime} 01^{\prime \prime} \mathrm{N} 34^{\circ} 51^{\prime}$ $46^{\prime \prime}$ E, 24.04.2011, 30.04.-7.05.2012, pitfalls (N.A. Stasyuk). Crimea: $2990^{7} \sigma^{7} 83$ 우 (TNU 10071-3, 10043-6, 10020-15, 100241, 10061-7, 10064-5, 10027-7, 10080-6, 10021-2, 10096-2, 101047, 10105-12, 10106-2, 10107-5, 10114-4, 10115-2, 10118-6, 10119- 
A

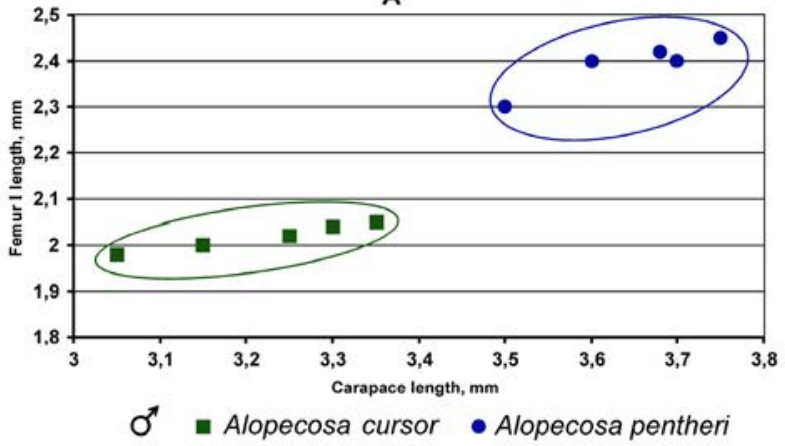

B

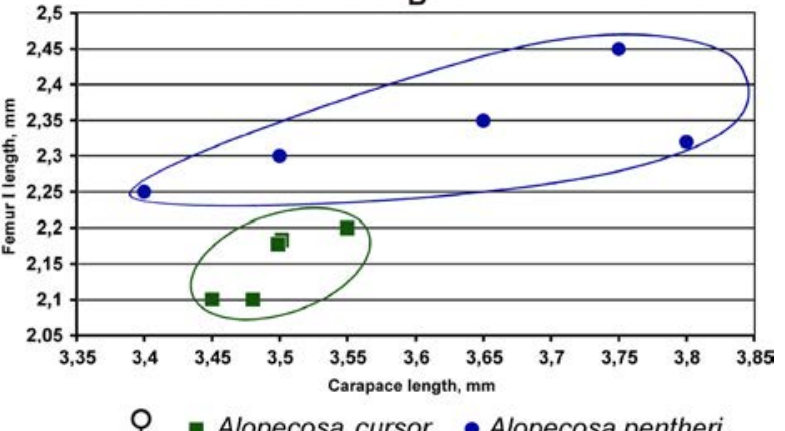

- Alopecosa cursor - Alopecosa pentheri

Fig. 10. Carapace length / femur I length ratio in males (A) and females (B) of Alopecosa cursor and A. pentheri from Crimea.

Рис. 10. Отношение длины карапакса к длине бедра I у самцов (А) и самок (B) Alopecosa cursor и A. pentheri из Крыма.

4, 10121-1, 10122-1, 10123-1, 10124-5, 10125-4, 10126-5, 10132 4, 10132-4, 10133-1, 10141-2, 10142-5), Chernomorskiy Distr., Tarkhankut peninsula, steppe between Dzhangul coast and Kipchak valley, $45^{\circ} 25^{\prime} 49^{\prime \prime} \mathrm{N} 32^{\circ} 31^{\prime} 11^{\prime \prime} \mathrm{E}-4^{\circ} 28^{\prime} 55^{\prime \prime} \mathrm{N} 32^{\circ} 35^{\prime} 43^{\prime \prime} \mathrm{E}$, June 2006, 2008, May-June 2012, April-September 2015, pitfalls (V Shaposhnikov, M.K., A.N.); $20^{7}$ (TNU SO-29/2/1, 31/1), Dzhankoi Distr., env. Solenoe Ozero Vill., steppe, $45^{\circ} 56^{\prime} 14^{\prime \prime} \mathrm{N} 34^{\circ} 26^{\prime} 48^{\prime \prime} \mathrm{E}$ $45^{\circ} 55^{\prime} 15^{\prime \prime} \mathrm{N} 34^{\circ} 29^{\prime} 19^{\prime \prime}$ E, April-May 2009, pitfalls (A.N.); $950^{7} 0^{7}$ 40 우우 (TNU 1732-1, 1739-1, 1749-6, 2035-7, 2370-15, 2399-4, 2386-3, 2559-5, 2591-7, 2617-5, 2711-2, 2712-2, 2713-3, 2714-3, 2716-5, 2721-2, 2736-7, 2866-8, 2867-12, 2868-9, 2870-5, 29075, 2908-5, 2947-2, 2948-8, 2949-11, 2950-15, 2952-12, 2953-5, 2970-9, 2973-21, 3157-1, 3186-6, 3188-15, 3271-4, 3284-2, 32851, 3308-1, 3322-12), Feodosiya Distr., Karadag Nature Reserve, $44^{\circ} 55^{\prime} \mathrm{N} 35^{\circ} 12^{\prime} \mathrm{E}$, April 2001, 2003, 2004, 2013, May 2006, 2007, 2009, April-July 2008, May-June 2012 (O.V. Kukushkin, M.K. A.N.); 1 ( (TNU 2599-15), Feodosiya Distr., Echki-Dag, $44^{\circ} 54^{\prime} \mathrm{N}$ $35^{\circ} 09^{\prime} \mathrm{E}, 1.06 .2008$ (A.N.); $4 \mathrm{O}^{\top} \mathrm{O}^{\top} 8$ 우우 (TNU 3059-23, 3065-5, 3067-1, 3073-3, 3094-2, 3101-2), Lenino Distr., S of Kerch peninsula, Opuk Nature Reserve, $45^{\circ} 02^{\prime} \mathrm{N} 36^{\circ} 13^{\prime} \mathrm{E}, 20-26.05 .2005,9-$ 12.05.2008, 31.05.-2.06.2011 (V.A. Gnelitsa, O.V. Kukushkin, A.N.); 205 O $^{7} O^{7} 135$ 우 (TNU 3290-41, 3291-5, 3292-2, V10-4, V11-8, V12-13, V13-2, V14-1, V15-6, V16-3, V24-2, V25-6, V268, V28-2, V38-2, V39-2, V43-5, V48-1, V53-1, V65-1), Lenino Distr., $\mathrm{N}$ of Kerch peninsula, Kazantip Nature Reserve, $45^{\circ} 28^{\prime} \mathrm{N}$ 3550'E, 2-10.05.2013, 27.03.-11.07.2016, pitfalls (I.F. Valyukh, M.K., A.N.); 10 O $^{7} \sigma^{7}$ (TNU 1652-4, 1653-7, 1655-16, 1699-2), Saky Distr., env. Pribrezhnaya railway station, sand, $45^{\circ} 09^{\prime} \mathrm{N} 33^{\circ} 30^{\prime}$ E, 6.04.-19.05.2000, pitfalls (M.K.); $1 \mathrm{O}^{7} 1$ ㅇ (TNU), Simferopol,

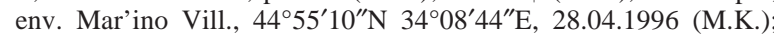
$4 O^{7} O^{7} 2$ 우 (TNU 962-6, 963-10, 965-7), Simferopol Distr., env. Lozovoe Vill., N side of quarry, Bairakly Mt. W slope, N44 $54^{\prime}$ 59.1" E34 ${ }^{\circ} 10^{\prime} 57.2^{\prime \prime}$, meadow, 18.04.-6.06.2000, pitfalls (M.K.); $2250^{7} 0^{7} 56$ 오 (TNU 1751-6, 1752-10, 1753-8, 1754-10, 1755-6, 1756-8, 1757-5, 1782-1, 1783-2, 1784-1, 1785-8, 1786-5, 1787-7, $1788-10,1844-14,1852-2,1853-5,1854-19,1855-9,1856-19$, 1857-17), Simferopol Distr., env. Skvortsovo Vill., steppe, $45^{\circ} 04^{\prime}$ $57^{\prime \prime} \mathrm{N} 33^{\circ} 49^{\prime} 48^{\prime \prime} \mathrm{E}$, March-May 2002, pitfalls (M.K.); $74 \bigcirc^{7} \mathrm{O}^{7} 57$ 우우 (TNU 2680-14, 2687-15, 2685-9, 2697-11, 2658-2, 2659-7, 26609, 2661-2, 2662-11, 2671-7, 2673-5, 2675-7, 2676-9, 2677-4), Sudak Distr., env. Mezhdurech'e Vill., meadows, $44^{\circ} 53^{\prime} \mathrm{N} 34^{\circ} 51^{\prime}$ E, April-May 2010 (M.K. Yusufova); $50^{7} 0^{7} 4$ 우 (ZMUT 07),

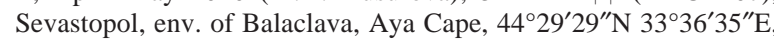
$170 \mathrm{~m}, 14.03 .2002$ (Yu.M. Marusik). AZERBAIJAN: $1 \mathrm{O}^{7}$ (ZMMU Az-10/01), Zuvand area, env. of Divagatch Vill., 38 $41^{\prime} 44^{\prime \prime} \mathrm{N}$ $48^{\circ} 22^{\prime} 52^{\prime \prime} \mathrm{E}, 1400 \mathrm{~m}$, semi-desert, 25-26.05.2003 (Yu.M. Marusik).

DIAGNOSIS. Males of $A$. pentheri can be easily distinguished from other species of the A. cursor group by having short, spine-like setae $(\mathrm{Se})$ on the venter of the abdomen (Figs $1 \mathrm{H}, 1 \mathrm{~J}-\mathrm{K}, 6 \mathrm{I}-\mathrm{J}$ ); other species have no such setae. Alopecosa pentheri is most similar to A. cursor by the shape of the male palps and epigyne. Males of the two species can be separated by the size of the palp (cf. Fig. 2A-B), shape of the tegular apophysis, and embolus. Alopecosa pentheri has closely spaced ventral $(\mathrm{Ov})$ and retrolateral $(\mathrm{Or})$ outgrowths of the tegular apophysis, and both outgrowths are equal in length and connected by a smoothly rounded lamella (vs. widely spaced, unequal in length and forming a right angle in A. cursor, cf. Fig. 3A-D). The median part of the embolus in A. pentheri is 5 times wider than the tip, and in $A$. cursor, it is 3 times wider than the tip (cf. Fig. 5F, L). Females of the two species are almost indistinguishable due to the variation of the septum and receptacles. The two species can be separated by the carapace length / femur I length ratio (cf. Fig. 10).

DESCRIPTION. $\sigma^{\top}$ of from Crimea.

Male: total length 6.0; carapace long 2.9, wide 2.0; leg length (Table 6a): I 7.29 (1.98, 0.98, 1.58, 1.65, 1.1); II 6.89 $(1.85,0.92,1.45,1.65,1.02)$; III $6.66(1.85,0.85,1.3,1.75$, 0.91); IV $9.01(2.35,0.98,1.81,2.62,1.25)$.

Palp as in Figs 2B, 3C-D, 4C-D, 5G-L: sperm duct not smoothly rounded and almost straight above subtegulum; prolateral tip of tegulum (Tt) not hidden by embolus (Figs 2B, 3C, 5G); terminal part of tegular apophysis wider than mesal part, anterior edge of tegular apophysis $(A t)$ forms nearly a right angle, with only the tip of the angle rounded, outgrowths of tegular apophysis closely spaced (in ventral view), both arms subequal in length in anterior view, connected by a smoothly rounded lamella (Fig. 3C-D); embolus relatively short.

Female: total length 6.7; carapace long 3.2, wide 2.15; leg length (Table 7a): I 6.94 (2.0, 1.0, 1.42, 1.5, 1.02); II $6.65(1.9,1.0,1.3,1.45,1.0)$; III 6.57 (1.82, 0.92, 1.2, 1.68, $0.95)$; IV $9.54(2.52,1.12,1.85,2.75,1.3)$.

Epigyne as in Figs $7 \mathrm{H}-\mathrm{K}, 8 \mathrm{~B}-\mathrm{C}$ : septum as wide as long, widened posteriorly, anterior part triangular; distance between receptacles is equal to their two diameters, copulatory duct about 2 times thinner than receptacle.

Variations $\left(+/ \sigma^{7}, \mathrm{n}=10 / 10\right)$ : total length $6.1-9.4 / 6.2-$ 7.4; carapace 3.4-3.8/3.5-3.75 long, 2.5-2.7/2.6-2.7 wide.

TYPE LOCALITY. Turkey, Central Anatolia, Kayseri, volcano Erdschias Dagh (= Mount Erciyes) [Nosek, 1905], ca. $38^{\circ} 31^{\prime} 45^{\prime \prime} \mathrm{N} 35^{\circ} 26^{\prime} 38^{\prime \prime} \mathrm{E}$.

DISTRIBUTION. East Mediterranean range: from Italy to Azerbaijan, south to Crete and north to the Crimea. In Crimea, the species is widespread over the entire peninsula. Because the climate in northern Crimea is the same as that in southern Ukraine, it is likely that the species may occur 


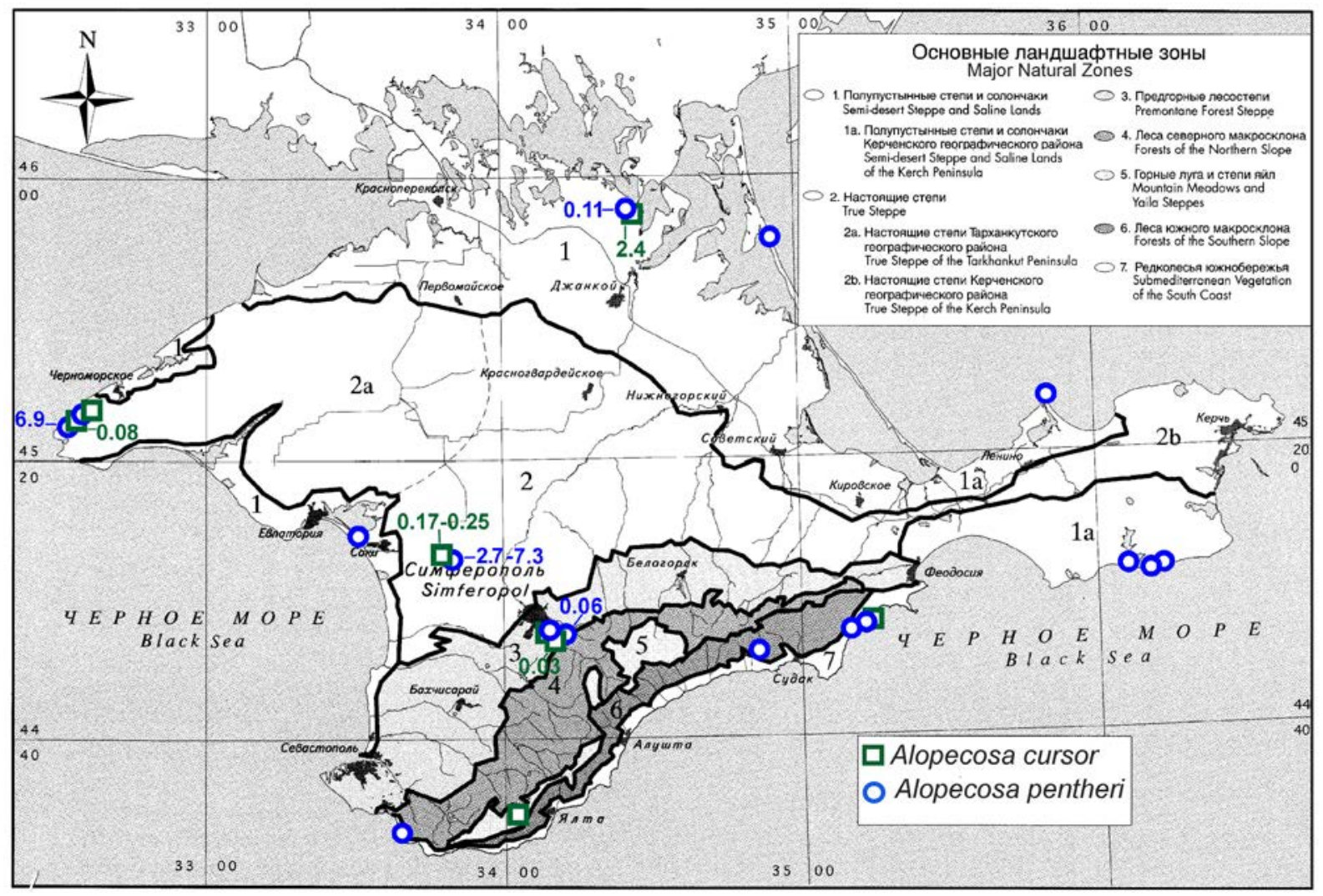

Fig. 11. Distribution records of Alopecosa cursor and A. pentheri in Crimea. Decimal numbers designate quantity of adult males per 100 pitfall-trap-days in habitats where both species occur in sympatry.

Рис. 11. Распространение Alopecosa cursor и A. pentheri в Крыму. Десятичные числа соответствуют количеству отловленных почвенными ловушками самцов на 100 ловушко-суток в биотопах с совместным обитанием обоих видов.

north of the peninsula. Some of the numerous records of $A$. cursor from north of the peninsula [cf. Polchaninova, Prokopenko, 2013] may refer to $A$. pentheri.

PHENOLOGY. In Crimea, adult males can be found from March to September with a peak of activity in AprilMay (Fig. 12).

HABITATS. In the Crimea, A. pentheri occurs from sea level to $400 \mathrm{~m}$ (Fig. 11). It inhabits semi-desert and true steppes (with Festuca, Stipa, Asphodelina, Artemisia, Leymus, Crataegus, Rosa, Paliurus), and maquis shrublands on the south coast (Pistacia mutica, Juniperus excelsa, Quercus pubescens). In the Crimea, A. pentheri prefers xerophytic habitats (also, see comments about habitat preference of A. cursor).

\section{Acknowledgements}

We wish to thank Z. Simons (Oxford) and D.V. Logunov (Manchester) for their help in getting the type material of A. passibilis; S.L. Esyunin (Perm) provided us with information on the type material of A. cursorioides; G.N. Azarkina (Novosibirsk) provided us with list of material from Novosibirsk area; M.M. Omelko (Vladivostok), G.N. Azarkina, A.A. Fomichev (Novosibirsk), and M.M. Kovblyuk (Simferopol) kindly checked drafts of manuscript. Also, we sincerely thank all the collectors who provided specimens for this study: L.A. Alekseeva, G.N. Azarkina, A. Bashchuk, N.R. Fritzén, I.V. Fyodorov, V.A. Gnelitsa, E.F. Huseynov, M.M. Kovblyuk, O.V. Kukushkin, I.T. Kuzne- tsov, T.V. Lobanova, O.L. Makarova, S.V. Ovchinnikov, S.N. Panteleeva, V. Shaposhnikov, V.V. Shaporinsky, N.A. Stasyuk, E.Yu. Sviridenko, I.F. Valyukh, and M.K. Yusufova. The English of the final draft was checked by Sarah Crews (San Francisco, USA).

\section{References}

Almquist S. 2005. Swedish Araneae, part 1 - families Atypidae to Hahniidae (Linyphiidae excluded) // Insect Systematics and Evolution. Vol.62. P.1-284.

Charitonov D.E. 1969. [Materials to fauna of spiders of USSR] // Uchenye Zapiski, Permskiy Gosudarstvennyi Universitet imeni A.M. Gorkogo. T.179. P.59-133 [in Russian].

Dunin P.M. 1984. [Fauna and ecology of the spiders of the Apsheron Peninsula, Azerbaijan SSR] // Fauna i ekologiya paukoobraznykh. Perm Univ. P.45-60 [in Russian].

Fomichev A.A. 2015. On the spider fauna (Arachnida: Aranei) of the Altai Republic (Russia) // Acta Arachnologica. Vol.64. No.2. P.63-70.

Fuhn I.E., Niculescu-Burlacu F. 1971. Arachnida. Fam. Lycosidae // Fauna Republicii Socialiste Romania. Bucuresti. Vol.5. 1$256 \mathrm{p}$.

Hahn C.W. 1831. Die Arachniden. C.H. Zeh'sche Buchhandlung, Nürnberg. Erster Band. $24 \mathrm{~S}$.

Helsdingen P.J. 2018. Fauna Europaea: Araneae. https://faunaeu.org, accessed on 9.11.2018.

Lugetti G., Tongiorgi P. 1969. Ricerche sul genere Alopecosa Simon (Araneae-Lycosidae) // Atti della Società Toscana di Scienze Naturali, Serie B. Vol.76. P.1-100 


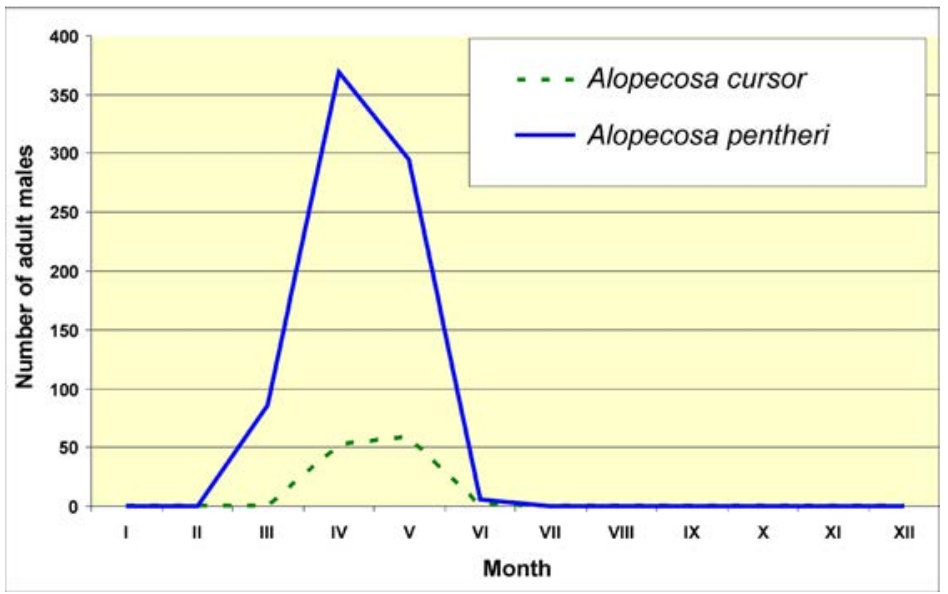

Fig. 12. Comparative phenology of males of Alopecosa cursor and A. pentheri based on specimens collected in pitfall traps in Crimea during 2000-2015.

Рис. 12. Сравнение фенологии самцов Alopecosa cursor и A. pentheri, основанное на сборах почвенными ловушками в Крыму в течение 20002015 гг.

Kovblyuk N.M. 2004. [Catalogue of the spiders (Arachnida: Aranei) of the Crimea] // Voprosy razvitiya Kryma. No.15. Problemy inventarizatsii krymskoi bioty. Simferopol: Tavriya-Plus P.211-262 [in Russian], 321 [English summary].

Kovblyuk M.M., Kastrygina Z.A. 2015. [Updated Catalogue of the Spiders (Arachnida, Aranei) of the Crimea] // Ukrainska Entomofaunistyka. T.6. No.2. P.1-81.

Kratochvil J. 1935. Araignées nouvelles ou non encore signalées en Yougoslavie // Folia Zoologica et Hydrobiologica, Riga. T.8. P.10-25.

Mirshamsi O., Saneei S., Aliabadian M., Ghassemzadeh F. 2015. New data on the wolf spiders of Iran (Aranei: Lycosidae) // Arthropoda Selecta. Vol.24. No.1. P.99-106.

Nosek A. 1905. Araneiden, Opilionen und Chernetiden // Penther A., Zederbauer E. (Hrsg.) Ergebnisse einer naturwissenschaftlichen Reise zum Erdschias-Dagh (Kleinasien). Annalen des Kaiserlich-Königlichen Naturhistorischen Hofmuseums in Wien. Bd.20. S.114-154.

Pickard-Cambridge O. 1885. Scientific results of the second Yarkand mission; based upon the collections and notes of the late Ferdinand Stoliczka, Ph. D. Araneidea. Government of India, Calcutta. $115 \mathrm{p}$

Polchaninova N.Yu., Prokopenko E.V. 2013. Catalogue of the spiders (Arachnida, Aranei) of Left-Bank Ukraine // Arthropoda Selecta. Suppl. No.2. 268 p.
Roewer C.F. 1955. Katalog der Araneae von 1758 bis 1940, bzw. 1954. 2. Band, Abt. a (Lycosaeformia, Dionycha [excl. Salticiformia]). Bruxelles: Institut Royal de Sciences Naturelles de Belgique. $751 \mathrm{~S}$.

Song D.X., Zhu M.S., Chen J. 1999. The spiders of China. Shijiazhuang: Hebei University of Science and Techology Publishing House. 640 pp.

Schmidt P. 1895. Beitrag zur Kenntnis der Laufspinnen (Araneae Citigradae Thor.) Russlands // Zoologische Jahrbücher, Abtheilung für Systematik, Geographie und Biologie der Thiere. Bd.8. H.4. S.439-484.

Strand E. 1917. Arachnologica varia XIV-XVIII // Archiv für Naturgeschichte. Bd.82. H.A2. S.70-76.

Tongiorgi P. 1966. Wolf spiders of the Pardosa monticola group (Araneae: Lycosidae) // Bulletin of the Museum of Comparative Zoology, Harvard. Vol.134. No.9. P.335-359.

Thaler K., Buchar J., Knoflach B. 2000. Notes on wolf spiders from Greece (Araneae, Lycosidae) // Linzer Biologische Beiträge. Vol.32. No.2. P.1071-1091.

WSC. 2018. World Spider Catalog. Version 19.5. Natural History Museum Bern, online at http://wsc.nmbe.ch, accessed on 9.11.2018. doi: $10.24436 / 2$

Responsible editor K.G. Mikhailov 
Appendix 1. Comparison of leg lengths in four species

Table 1a. Leg length in male of Alopecosa cursor.

\begin{tabular}{|l|l|l|l|l|l|l|}
\hline $\mathrm{O}^{7}$ & $\mathrm{Fe}$ & $\mathrm{Pa}$ & $\mathrm{Ti}$ & $\mathrm{Mt}$ & $\mathrm{Ta}$ & Total \\
\hline I & 2.12 & 1.12 & 1.6 & 1.68 & 1.2 & 7.72 \\
\hline II & 2.02 & 1.04 & 1.45 & 1.66 & 1.12 & 7.29 \\
\hline III & 2.0 & 1.0 & 1.4 & 1.88 & 1.05 & 7.33 \\
\hline IV & 2.6 & 1.15 & 1.9 & 2.78 & 1.32 & 9.75 \\
\hline
\end{tabular}

Table 2a. Leg length in female of Alopecosa cursor.

\begin{tabular}{|l|l|l|l|l|l|l|}
\hline$q$ & $\mathrm{Fe}$ & $\mathrm{Pa}$ & $\mathrm{Ti}$ & $\mathrm{Mt}$ & $\mathrm{Ta}$ & Total \\
\hline $\mathrm{I}$ & 2.29 & 1.2 & 1.6 & 1.7 & 1.18 & 7.97 \\
\hline II & 2.18 & 1.15 & 1.5 & 1.72 & 1.12 & 7.67 \\
\hline III & 2.12 & 1.12 & 1.42 & 2.0 & 1.1 & 7.76 \\
\hline IV & 2.88 & 1.28 & 2.12 & 3.22 & 1.42 & 10.92 \\
\hline
\end{tabular}

Table 3a. Leg length in male of Alopecosa cursorioides.

\begin{tabular}{|l|l|l|l|l|l|l|}
\hline $\mathrm{O}^{7}$ & $\mathrm{Fe}$ & $\mathrm{Pa}$ & $\mathrm{Ti}$ & $\mathrm{Mt}$ & $\mathrm{Ta}$ & Total \\
\hline I & 2.29 & 1.12 & 1.75 & 1.9 & 1.22 & 8.28 \\
\hline II & 2.18 & 1.14 & 1.62 & 1.82 & 1.12 & 7.88 \\
\hline III & 2.12 & 1.02 & 1.55 & 2.1 & 1.08 & 7.87 \\
\hline IV & 2.85 & 1.22 & 2.2 & 3.0 & 1.39 & 10.66
\end{tabular}

Table 4a. Leg length in female of Alopecosa cursorioides.

\begin{tabular}{|l|l|l|l|l|l|l|}
\hline$q$ & $\mathrm{Fe}$ & $\mathrm{Pa}$ & $\mathrm{Ti}$ & $\mathrm{Mt}$ & $\mathrm{Ta}$ & Total \\
\hline I & 2.25 & 1.12 & 1.65 & 1.65 & 1.12 & 7.79 \\
\hline II & 2.12 & 1.12 & 1.48 & 1.62 & 1.08 & 7.42 \\
\hline III & 2.08 & 1.02 & 1.4 & 1.92 & 1.05 & 7.47 \\
\hline IV & 2.78 & 1.25 & 2.11 & 3.1 & 1.42 & 10.66 \\
\hline
\end{tabular}

Table 5a. Leg length in male of Alopecosa passibilis.

\begin{tabular}{|l|l|l|l|l|l|l|}
\hline$\bigcirc^{7}$ & $\mathrm{Fe}$ & $\mathrm{Pa}$ & $\mathrm{Ti}$ & $\mathrm{Mt}$ & $\mathrm{Ta}$ & Total \\
\hline $\mathrm{I}$ & 2.58 & 1.32 & 2.2 & 2.0 & 1.5 & 9.6 \\
\hline
\end{tabular}

Table 6a. Leg length in male of Alopecosa pentheri.

\begin{tabular}{|l|l|l|l|l|l|l|}
\hline $\mathrm{O}^{7}$ & $\mathrm{Fe}$ & $\mathrm{Pa}$ & $\mathrm{Ti}$ & $\mathrm{Mt}$ & $\mathrm{Ta}$ & Total \\
\hline $\mathrm{I}$ & 1.98 & 0.98 & 1.58 & 1.65 & 1.1 & 7.29 \\
\hline II & 1.85 & 0.92 & 1.45 & 1.65 & 1.02 & 6.89 \\
\hline III & 1.85 & 0.85 & 1.3 & 1.75 & 0.91 & 6.66 \\
\hline IV & 2.35 & 0.98 & 1.81 & 2.62 & 1.25 & 9.01 \\
\hline
\end{tabular}

Table 7a. Leg length in female of Alopecosa pentheri.

\begin{tabular}{|l|l|l|l|l|l|l|}
\hline q & $\mathrm{Fe}$ & $\mathrm{Pa}$ & $\mathrm{Ti}$ & $\mathrm{Mt}$ & $\mathrm{Ta}$ & Total \\
\hline $\mathrm{I}$ & 2.0 & 1.0 & 1.42 & 1.5 & 1.02 & 6.94 \\
\hline II & 1.9 & 1.0 & 1.3 & 1.45 & 1.0 & 6.65 \\
\hline III & 1.82 & 0.92 & 1.2 & 1.68 & 0.95 & 6.57 \\
\hline IV & 2.52 & 1.12 & 1.85 & 2.75 & 1.3 & 9.54 \\
\hline
\end{tabular}

